\title{
Systematics, taxonomy and floristics of Brazilian Rubiaceae: an overview about the current status and future challenges
}

Sistemática, taxonomia e florística das Rubiaceae brasileiras: um panorama sobre o estado atual e futuros desafios

\author{
Piero Giuseppe Delprete ${ }^{1} \&$ Jomar Gomes Jardim ${ }^{2}$
}

\begin{abstract}
The Rubiaceae is the fourth Angiosperm family in number of species in the World and in the Neotropics. Its overwhelming diversity and presence in most biomes, and at most vegetation layers, makes this family one of the most important components of tropical vegetation. During the last two decades, family classification went through several reorganizations, mostly influenced by the advent of molecular phylogenetic studies, and many taxonomic revisions and floristic studies on Brazilian Rubiaceae have become available. In view of the considerable amount of literature that has recently been produced on Neotropical Rubiaceae, the present work has two main objectives: the first is to offer an overall view of the most recent family classification with emphasis on the genera of Rubiaceae occurring in Brazil, and to indicate particular taxa that are still in need of phylogenetic and taxonomic studies; the second objective is to present a short discussion on the state of floristic and taxonomic knowledge with respect to the various regions of Brazil, indicating the taxa and the geographic areas that need to be studied.

Key words: Rubiaceae, Brazil, classification, floristics, systematics, taxonomy.

\section{Resumo}

Rubiaceae é a quarta família em número de espécies entre as Angiospermas no Mundo e no Neotrópico. A grande diversidade de espécies com representantes na maioria dos bioma, ocupando os diferentes estratos vegetacionais, fazem desta família um dos mais importantes componente da vegetação tropical. Durante as duas últimas décadas a classificação da família sofreu várias reorganizações, principalmente pela influência de estudos filogenéticos moleculares, e muitos estudos florísticos e revisões taxonômicas foram recentemente produzidos sobre Rubiaceae Neotropicais. Considerando a grande quantidade de literatura que foi recentemente produzida sobre estes assuntos, o presente trabalho tem dois objetivos principais: o primeiro é fornecer uma visão geral sobre a mais recente classificação da família com ênfase nos gêneros de Rubiaceae que ocorrem no Brasil, indicando os táxons que necessitam de estudos filogenéticos e taxonômicos; o segundo, é apresentar uma breve discussão sobre o estado de conhecimento florístico e taxonômico nas várias regiões do Brasil, indicando os táxons e as áreas geográficas que precisam de mais estudos.

Palavras-chave: Rubiaceae, Brasil, classificação, florística, sistemática, taxonomia.
\end{abstract}

\section{Introduction}

The Rubiaceae is the fourth family in number of species in the Angiosperms (Tab. 1), after Orchidaceae, Asteraceae and Leguminosae. Delprete (2004a) esteemed that the family is made of about 650 genera and 13,000 species worldwide; these numbers were later confirmed by Govaerts et al. (2007), in their world checklist, by reporting
611 genera and 13,100 species. The difference in number of genera between these two accounts is partly due to advent of molecular phylogenies and recent morphological comparisons that resulted in the reduction to synonymy of many genera. According to Delprete (2004a), in the Neotropics are present by about 217 genera and 5,000 species of Rubiaceae.

\footnotetext{
${ }^{1}$ Herbier de Guyane (CAY), UMR AMAP, Institut de Recherche pour le Développement (IRD), Boite Postal 165, 97323 Cayenne, French Guiana (France). piero.delprete@ird.fr

${ }^{2}$ Universidade Federal do Rio Grande do Norte, Centro de Biociências, Depto. Botânica, Ecologia e Zoologia, Campus Universitário Lagoa Nova, C.P. 1524, 59072-970, Natal, RN, Brazil. j.jardim@yahoo.com.br
} 
Table 1 - Summary of the five largest families of flowering plants, with approximate number of species in the world (Mabberley 2008; Govaerts et al. 2007), in the Neotropics (Delprete 2004), and in the Guyana Shield (Funk et al. 2007).

\begin{tabular}{lllllr}
\hline \multicolumn{2}{c}{ World } & & \multicolumn{2}{c}{ Neotropics } & \multicolumn{2}{c}{ Guyana Shield } \\
\hline Asteraceae & 23,600 & Asteraceae & 8,000 & Leguminosae & 1,032 \\
Orchidaceae & 22,500 & Orchidaceae & 7,000 & Orchidaceae & 1,020 \\
Leguminosae & 19,500 & Leguminosae & 6,700 & Rubiaceae & $\mathbf{7 4 2}$ \\
Rubiaceae & $\mathbf{1 3 , 1 0 0}$ & Rubiaceae & $\mathbf{5 , 0 0 0}$ & Melastomataceae & 534 \\
Poaceae & 10,550 & Poaceae & 3,300 & Poaceae & 526 \\
\hline
\end{tabular}

Distribution and habitat - The Rubiaceae is a cosmopolitan family, predominantly pantropical, and with a small portion of species of extratropical distribution. Almost one half of the species (and about one third of the genera) occur in the Neotropics. In South America, they are adapted to virtually every habitat: from páramo to arid and desertic environments. Rubiaceae are especially diverse in the Amazon Basin, Andean cloud forests, cerrados (including campos rupestres), caatingas, restingas, and the Atlantic forests of Brazil. The two main centers of endemism in the Neotropics are the Guyana Highlands and the Greater Antilles. Habit - The Rubiaceae is well represented at all layers of tropical vegetation, with all kinds of habits, as herbs, shrubs, lianas, and from small trees to tall canopy trees, and all dimensions, ranging from 5 $\mathrm{mm}$ tall (Spermacoce spp.) to $55 \mathrm{~m}$ tall (Chimarrhis spp.). Most species of Hillia Jacq., Cosmibuena Ruiz \& Pav., and several species of Notopleura (Benth. \& Hook. f.) Bremek. and Psychotria L. are epiphytic shrubs adapted to live in the forest canopy. Limnosipanea Hook. f. is a short-seasonal, semi-aquatic herb endemic to seasonally inundated habitats of central Brazil and the Venezuelan llanos. Many members of the Spermacoceae are herbs and subshrubs frequently found in disturbed habitats (e.g., cow pastures and forest edges).

Ecological importance - Because of their abundance, diversity, and presence at all vegetational layers, the Rubiaceae are an important factor for ecological studies in tropical regions, in terms of floristic and sociological composition, comparison among floristic composition of world tropical vegetation, observation and comparison of different vegetational layers (herbs, shrubs, trees, lianas), comparison of different habitats (savanna, restinga, open fields, forests, etc.), and particularly important at the undercanopy layer of tropical forests. Also, when compared with the other large flowering plant families (Orchidaceae and Leguminosae), the Rubiaceae are the family better fitted to be used in ecological analysis, because the Orchidaceae are mostly herbaceous, and the Leguminosae are probably taxonomically less studied than the Rubiaceae. Also, the Rubiaceae, along with the Melastomataceae, is the family that supplies most edible fruits to tropical birds (Bremer \& Eriksson 1992). In conclusion the Rubiaceae is an important indicator to be used as a proxy for ecological studies and conservation status of tropical vegetation.

Diagnostic characters - Field recognition of the family Rubiaceae is relatively easy, because of the following diagnostic characters:

1) leaves commonly opposite, rarely whorled (3-6 per node), or appearing whorled because of leaflike stipules (Galium L.) or axillary short shoots (e.g., Spermacoce L.);

2) leaf blades undivided (exceptionally deeply lobed in Genipa infundibuliformis Zappi \& Semir and several species of Pentagonia Benth.);

3) leaf margins always entire (never dentate);

4) stipules intrapetiolar (interpetiolar in Elaeagia Wedd. and Capirona Spruce; rarely reduced to a line in Perama Aubl.);

5) flowers commonly actinomorphic, rarely zygomorphic;

6) corollas gamopetalous (except for Dialypetalanthus Kuhlm., with distinct petals), (3)4-5(11-13(-15))-merous (Riodocea Delprete has 13-15-merous corollas, being the highest merosity in the Rubiaceae);

7) stamens commonly as many as corolla lobes (except for Dialypetalanthus, with two rows of 15-25 stamens);

8) ovary inferior, rarely some fruits becoming falsely half-superior (e.g., Gleasonia Standl., Platycarpum Bonpl.) or superior (Pagamea Aubl.) at maturity. 


\section{Past and present of the family position and delimitation}

Cronquist (1981) positioned the Rubiaceae in the Class Asteridae, Order Rubiales, near the Theligonaceae, family with only the genus Theligonum L. (Wunderlich 1971). He considered the Rubiales as narrowly related with the orders Gentianales and Dipsacales, and sister family of the Caprifoliaceae (but he erroneously supposed that the Asteraceae originated from the Rubiaceae). The phylogenetic studies of Chase et al. (1993), Struwe et al. (1994) and Backlund et al. (2000) demonstrated that the family Rubiaceae is a monophyletic group of the order Gentianales, along with the families Gentianaceae, Loganiaceae, Gelsemiaceae and Apocynaceae s.l. (incl. Asclepiadaceae). These results were integrated in the last Angiosperm classification proposed by Takhtajan (1997). The positioning of the Rubiaceae in the Gentianales was later confirmed by the phylogenies produced by the Angiosperm Phylogeny Group (APG 1998, 2003, 2009), where the family is positioned on a basal clade. According to these studies, the Rubiaceae is the family with the highest number of species in the order, with about $66 \%$ of the species, followed by the Apocynaceae with ca. 4700 spp., the Gentianaceae with ca. 1650 spp., the Loganiaceae with ca. 400 spp., and the Gelsemiaceae with 11 spp. (Struwe \& Albert 2002).

A few genera previously positioned in other families, have recently been shown to belong to Rubiaceae. The genus Theligonum, characterized for having leaves apparently alternate (in fact, an extreme case of anysophylly) and unilocular, uniovulate ovary, was historically positioned in its own monotypic family. Darwin (1976) transferred this genus to the Rubiaceae, in the monotypic tribe Theligoneae of the subfamily Rubioideae, a decision that was followed by Robbrecht (1988) using morphological data, and that was supported by the molecular phylogenies of Bremer et al. (1995).

The genus Dialypetalanthus was initially positioned in the Rubiaceae by Kuhlmann (1925), and subsequently transferred to the Dialypetalanthaceae by Rizzini \& Occhioni (1949), who suggested a systematic position in the Order Myrtales. Cronquist (1981) positioned this genus and family in the Order Rosales, and Nicholas \& Baijnath (1994) in the Order Cornales. Piesschaert et al. (1997), after a detailed analysis with morphological and anatomical characters were unable to indicate a definitive family position of Dialypetalanthus and suggested a relationship with the orders Myrtales or Gentianales, and a probable relationship with the Rubiaceae. Delprete (1998d) after a morphological analysis confirmed that it should be returned to the original position suggested by Kuhlmann (1925), and more precisely in the tribe Rondeletieae sensu Delprete (1999d). Fay et al. (2000) with a phylogenetic analysis using $r b c \mathrm{~L}$ confirmed its positioning in the Rubiaceae, subfamily Ixoroideae, near Condaminea DC., Pogonopus Klotzsch and Calycophyllum DC. (Tribe Condamineeae sensu Kainulainen et al. 2010), as was indicated by Delprete (1998d).

According to the phylogenies published by Backlund et al. (2000), the Rubiaceae represent the basal group in the Order Gentianales. For this reason, the dating with the help of molecular phylogenies could also indicate the age and the center of origin of the Order Gentianales. As suggested by several authors (e.g., Struwe \& Albert 2002), the Rubiaceae, and therefore the Gentianales, originated at least 70 millions years ago. However, Bremer \& Eriksson (2009), using molecular phylogenies calibrated with carbondating of several fossils, estimated that the Rubiaceae originated about 90 millions years ago.

In conclusion, following the results of the molecular phylogenies above cited, the Rubiaceae where demonstrated to be a monophyletic group distinguishable from the other families in the Order Gentianales by the following set of morphological and anatomical characters: 1) inferior ovary (with some exception in the remainder of the order); 2) lack of internal phloem (present in the reminder of the order, with a few exceptions); 3) obturator; 4) casparian thickening; and 5) anticipated sympetaly (Erbar 1991).

\section{Internal classification of the family Rubiaceae}

Rubiaceae classification at the subfamilial and tribal levels went through several important rearrangements during the last decades. Bremekamp (1934) published an article that had a great influence by contemporary botany, where he criticized the systems proposed by Baillon (1880) and Schumann (1891), because they were made of paraphyletic groups obtained through the utilization of a dichotomic classification based on unique characters. He declared that the groups defined by a sole character cannot be natural and that the seed wings of several general genera do not represent an important taxonomic character, in contrast with Baillon (1880), who divided the family into two 
groups, one with uni-ovulate taxa, and the other with multi-ovulate taxa. Bremekamp (1934) was also the first rubiologist treating the ixoroid mechanism of pollen presentation as an important taxonomic character. A few years later, Bremekamp (1940) emphasized his skepticism against the classification proposed by Schumann (1889, 1891), declaring it to be non-satisfactory and with artificial and ill-defined tribes. In this little known publication, Bremekamp (1940) predicted the path towards the Rubiaceae classification of the following decades, declaring that fruit fleshiness should be regarded as a secondary character and that the taxonomic characters of primary importance will be found in "... presence or absence of hairs in the corolla throat; the place where the stamens are inserted in the tube; the presence or absence of floral dimorphism; the uni-or bisexuality of the flowers; the insertion and the shape of the placenta; the number of ovary cells and the presence or absence of false septs (septa); the nature the stipules; the position of the inflorescences, etc. These characters, however, are at present but imperfectly known, and therefore a satisfactory subdivision can be given, the genera themselves will have to be studied in more detail."

Verdcourt (1958), deeply influenced by Bremekamp, was the second rubiologist to classify the Rubiaceae based on total evidence, studying a new series of taxonomic characters, including the observation of chromosomes, vestiture of reproductive parts, of the stipules, presence or absence of calcium oxalate crystals, presence of albumen in the seeds, embryo structure, and mechanism of pollen presentation. He divided the Rubiaceae into three subfamilies (Rubioideae, Cinchonoideae and Guettardoideae), and 28 tribes.

In his last work published on Rubiaceae classification, Bremekamp (1966) analyzed the innovations proposed by Verdcourt, with which he was generally in agreement. But, in contrast with his previous classification (Bremekamp 1934) and with that proposed by Verdcourt (1958), he divided the Rubiaceae into eight subfamilies and 43 tribes.

The last comprehensive classification proposed before the instars of molecular phylogenies was that of Robbrecht (1988, 1993). This classification was generally influenced by those of Verdcourt and Bremekamp. According with Verdcourt, he recognized four subfamilies, by dividing the Guettardoideae sensu Verdcourt into the two subfamilies Ixoroideae and Antirheodeae, and, similarly to Bremekamp, he recognized 44 tribes (one more than Bremekamp). Robbrecht's (1988,
1993 ) classification was used in most contemporary treatments, as the Plant-Book (Mabberley 1997) and the Flora of Ecuador, sometimes with some modifications (Andersson 1993, 1994).

With the advent of molecular phylogenies, during the last decades was demonstrated that the Rubiaceae are better divided into three subfamilies: Cinchonoideae, Ixoroideae and Rubioideae. Many studies were dedicated to phylogenetic studies of the family internal classification, subfamilies, tribes, or even smaller groups in order to have a general picture of the family backbone, and subsequently to clarify tribal and generic delimitations $(r b c \mathrm{~L}$, Bremer \& Jansen 1991; rbcL and $n d h \mathrm{~F}$, Andreasen \& Bremer 1996; Bremer 1996; Bremer et al. 1999; rps 16 and trnL-F, Rova et al. 2002). These studies showed that many characters used by Bremekamp (1934, 1954, 1966), Verdcourt (1958) and Robbrecht $(1988,1993)$ to define subfamilies and tribes, are highly plastic in an evolutionary sense, and that, for example, mesocarp fleshiness, placentation type, and number of ovules per locule are much more easily interchangeable than previously thought. This does not mean that these characters should be abandoned, but, to the contrary, the morphology, anatomy, and palynology of the Rubiaceae should be re-evaluated in order to understand their true evolutionary and taxonomic importance in an evolutionary contest.

During the last fifteen years, many other molecular phylogenetic studies were published (Achille et al. 2006; Andersson \& Antonelli 2005; Andersson \& Rova 1999; Andersson et al. 2001; Andreasen \& Bremer 1996; Andreasen \& Bremer 2000; Andreasen et al. 1999; Bremer \& Manen 2000; Bremer \& Thulin 1998; Bremer et al. 1999; Cortés-B. 2003; Delprete \& Cortés-B. 2004; Dessein 2003; Lantz 2003; Motley et al. 2005; Persson 2000a,b; Piesschaert et al. 2000; Razafimandimbison \& Bremer 2001, 2002; Rova et al. 2002; Stoffelen et al. 1996), with the intent of clarifying the subfamilial, tribal and generic delimitation in the Rubiaceae. Following these studies, a family classification for a general overview on the systematic significance of pollen in the Rubiaceae was published by Dessein et al. (2005), where significant correlations with tribal delimitations were detected.

A new family classification was proposed by Robbrecht \& Manen (2006), based on $r b c \mathrm{~L}$, $r p s 16, t r n \mathrm{~L}-t r n \mathrm{~F}$ and $a t p \mathrm{~B}-r b c \mathrm{~L}$. In the phylogenies obtained, Luculia Sweet and Coptosapelta Korth. were found (as in previous phylogenies of Bremer 
and collaborators) at a basal position, as sister taxa to the remainder of the family, which they included in the tribe Coptosapelteae. The "supertree" classification proposed by Robbrecht and Manen (2006) was innovative, by proposing only two subfamilies, the Cinchonoideae and the Rubioideae. The subfamily Cinchonoideae was further divided into three groups: the tribe Coptosapelteae, the supertribe Ixoridinae (14 tribes and alliances) and the supertribe Cinchonidinae ( 7 tribes and complexes). The subfamily Rubioideae was divided into three groups: basal Rubioideae (Colletoecema E.M.A. Petit and 5 tribes), the supertribe Psychotriidinae (6 tribes), and the supertribe Rubiidinae ( 8 tribes). Summarizing, this classification proposed the division into two groups, a total of 40 tribes and several genera at unresolved positions (although many genera were not even mentioned in the classification), and reducing several previously recognized tribes to the level of subtribes.

The last comprehensive family classification based on molecular phylogeny of 534 taxa and 329 genera (about half the genera recognized in the family), with sequences of five chloroplast regions ( $r b c \mathrm{~L}$, trnT-F, rps 16 , atpB-rbcL, $n d h \mathrm{~F})$, was published by Bremer and Eriksson (2009) that produced a highly resolved tree, and with the main goal of dating the main clades with the available fossil records. Based on the phylogeny obtained, the authors maintained the division of the family into three subfamilies (Cinchonoideae, Ixoroideae and Rubioideae) and 44 tribes. Because several data sets used in this analysis were in common with those used by Robbrecht \& Manen (2006), most of the groups recognized are quite similar, but Bremer and Eriksson (2009) positioned them at different taxonomic ranks, following previous classifications proposed by the Bremer's working group. Because this latest classification seems to be widely accepted (although not yet comprehensive, as usable DNA is not yet available for all the genera), it is here chosen as the main frame for our discussion of taxonomic groups of Rubiaceae present in Brazil. The main morphological characters of the three subfamilies currently recognized in the Rubiaceae are presented in Table 2.

\section{Classification of the Rubiaceae and status of taxonomic groups present in Brazil}

This presentation is an updated summary on the current status of the genera of Rubiaceae present in Brazil, organized according to Bremer \& Eriksson (2009) classification, and recent phylogenetic studies of several tribes (as indicated in the text). This presentation is intended to help the Rubiaceae specialists with the updates of recent literature, and to indicate taxonomic groups present in Brazil that need particular attention for possible phylogenetic, taxonomic, and floristic studies.

Tribes Coptosapelteae and Luculieae: Coptosapelta and Luculia are located at a basal position in the Rubiaceae, at a sister position, with respect to the rest of the family; they are both Asiatic genera that do not occur in Brazil.

Table 2 - Table summarizing the main characters of the three subfamilies currently recognized in the family Rubiaceae, with emphasis on Neotropical genera (from Delprete 2004).

\begin{tabular}{|c|c|c|c|}
\hline & Cinchonoideae & Ixoroideae & Rubioideae \\
\hline Habit & trees, shrubs, lianas & trees, shrubs, herbs, vines & $\begin{array}{l}\text { mostly herbs and shrubs, } \\
\text { rarely trees }\end{array}$ \\
\hline Stipules & $\begin{array}{l}\text { entire, rarely bifid (not } \\
\text { fimbriate) }\end{array}$ & $\begin{array}{l}\text { entire, rarely bifid (not } \\
\text { fimbriate) }\end{array}$ & $\begin{array}{l}\text { entire, bifid, or fimbriate } \\
\text { (Spermacoceae sensu lato) }\end{array}$ \\
\hline Calycophylls & $\begin{array}{l}\text { absent (present in } \\
\text { Kerianthera) }\end{array}$ & $\begin{array}{l}\text { present in many genera (or } \\
\text { absent) }\end{array}$ & $\begin{array}{l}\text { absent (present in } \\
\text { Oreopolus) }\end{array}$ \\
\hline Flora symmetry & $\begin{array}{l}\text { actinomorphic } \\
\text { (zygomorphic in Coutarea } \\
\text { and Hillia) }\end{array}$ & $\begin{array}{l}\text { actinomorphic (zygomorphic } \\
\text { in Henriquezieae and } \\
\text { Posoqueriae) }\end{array}$ & $\begin{array}{l}\text { actinomorphic (corolla } \\
\text { tube basally gibbous in } \\
\text { Palicourea) }\end{array}$ \\
\hline Stamens insertion & $\begin{array}{l}\text { at base, middle of tube or } \\
\text { near corolla mouth }\end{array}$ & $\begin{array}{l}\text { at middle of corolla tube or } \\
\text { near mouth }\end{array}$ & $\begin{array}{l}\text { at middle of tube or near } \\
\text { corolla mouth }\end{array}$ \\
\hline $\begin{array}{l}\text { Raphides } \\
\text { of Ca-oxalate }\end{array}$ & $\begin{array}{l}\text { absent (present in Hillia } \\
\text { and Hamelia) }\end{array}$ & absent & present \\
\hline
\end{tabular}




\section{Subfamily Cinchonoideae}

1.1 Tribe Chiococceae sensu lato (ChiococceaeCatesbaeeae-Complex; Motley et al. 2005)

A tribe of about 28 genera and 190 species (Motley et al. 2005), with the main center of diversity in the Greater Antilles, several genera in Central and South America, and a few genera in the islands of the South Pacific. In Brazil are present the following genera: Chiococca P. Browne, Coutarea Aubl., Erithalis P. Browne, Exostema (Pers.) P. Browne, and Salzmannia DC.

Literature: A study of the pollen of most genera of this tribe was presented by Huysmans et al. (1999), and a molecular phylogeny of this tribe was recently published by Motley et al. (2005). A species realignment and a new species of Chiococca for coastal Brazil was recently published by Delprete (2004b).

1.2 Tribe Cinchoneae (defined as Bremer \& Eriksson 2009, with the genera included by Andersson \& Antonelli 2005)

A Neotropical tribe of 6-7 genera (Andersson \& Antonelli 2005). In Brazil is represented by Ciliosemina Antonelli, Cinchonopsis L. Andersson, Ladenbergia Klotzsch, and Remijia DC. (incl. Cephalodendron Steyerm.). The genus Maguireocharis Steyerm. was positioned in the Cinchoneae by Andersson (1995), but Andersson \& Antonelli (2005) where unable to test its position due to lack of useful DNA; it is tentatively maintained in this tribe, pending molecular phylogenetic studies to confirm its position.

Literature: A molecular phylogeny was recently published by Andersson \& Antonelli (2005). A synopsis of the species of Ladenbergia was published by Andersson (1997).

Taxonomic revision needed: The genus Remijia, with about 40 species widely distributed in South America, and many species in the Amazon basin, is in need of a taxonomic revision.

\subsection{Tribe Guettardeae}

A Pantropical tribe with many Neotropical genera. The generic delimitations within the tribe have been recently tested by Achille et al. (2006), where Guettarda L. and Antirhea Juss., as traditionally defined, were shown to be paraphyletic; however, several taxa need to be added to these phylogenies in order to have a general view about the definition of the tribe and its generic delimitations. Following the phylogenies produced by Achille et al. (2006), Delprete et al. (2010) proposed a redelimitations of the genera of this tribe, and Taylor \& Gereau (2010a) and Delprete et al. (2010) proposed several new combinations in Chomelia Jacq. and Stenostomum C.F. Gaertn. Additionally, some genera have been transferred from the Rondeletieae to this tribe, based on molecular phylogenies, by Rova et al. (2009). According to these recent generic rearrangements, in Brazil are present the following genera of the tribe Guettardeae: Chomelia, Gonzalagunia Ruiz \& Pav., Guettarda, Machaonia Bonpl., Malanea Aubl., and Stenostomum.

1.4 Tribe Rondeletieae (as defined by Rova et al. 2009)

A tribe of about 15 genera occurring mostly in the Neotropics, with center of diversity in Central America and the Greater Antilles, many species in Colombia and Ecuador, and a few genera in the South Pacific. A recent molecular phylogenetic analysis focused on this tribe was published by Rova et al. (2009). Although a few genera are present in northern South America, no species of this tribe has been reported from Brazil.

\subsection{Tribe Hamelieae}

A Neotropical tribe, with center of diversity in Mexico, Central America, and the South America Andes. In Brazil is represented by a few species of Deppea Cham. \& Schltdl., Hamelia Jacq., Hoffmannia Sw., and Patima Aubl..

Literature: A revision of Hamelia was published by Elias (1976). Delprete et al. (2005) revised Patima, and synonymized Hoffmannia megistophylla Standl. (from Northern Brazil) with Patima guianensis Aubl., a species previously know only from the Guianas; in this work, Delprete also proposed a list of the genera to be included in the Hamelieae, based on overall morphological similarities. A second species of Patima, from Guyana, was recently described by C.M. Taylor (in Taylor \& Lorence 2010).

Revision needed: The genus Hoffmannia, with many species in Mexico, Central America, and the South America Andes, and a few species in Brazil, is in need of a taxonomic revision.

\subsection{Tribe Hillieae}

A Neotropical tribe, that includes Hillia and Cosmibuena, both present in Brazil.

Literature: Taxonomic revisions of these two genera were published by C.M. Taylor $(1992,1994)$. 


\section{Chione}

According with the phylogenies of D.W. Taylor (2003) and Bremer \& Eriksson (2009), Chione DC. is positioned as sister taxon of the tribes Hamelieae and Hillieae. One species of this genus has been reported from western Amazonian Brazil (Delprete \& Taylor 2008).

Literature: A taxonomic revision of Chione has recently been published by D.W. Taylor (2003).

Work needed: Further phylogenetic studies are needed to clarify the tribal position of this genus.

\subsection{Tribe Hymenodictyeae}

A paleotropical tribe, absent in Brazil.

\subsection{Tribe Naucleeae}

A pantropical tribe. In Brazil is represented by Cephalanthus L. and Uncaria Schreb.

Literature: The only species of Cephalanthus present in Brazil, C. glabratus (Spreng.) K. Schum., has been fully described by Delprete et al. 2004. The two species of Uncaria present in South America, $U$. guianensis Aubl. and U. tomentosa (Willd. ex Roem. \& Schult.) DC., have been fully described by Steyermark (1974).

\subsection{Tribe Isertieae}

A Neotropical tribe, with two genera: Isertia Schreb. (incl. Yutajea Steyerm.) and Kerianthera J.H. Kirkbr., both present in Brazil. Bremer \& Thulin (1998) with a phylogenetic analysis using $r b c \mathrm{~L}$ restricted the tribe to Isertia (incl. Yutajea) and Kerianthera (confirming the conclusions of Delprete 1996). Isertia is a genus of about 15 species ranging from Mexico through Brazil, and Kerianthera is a genus of two species, both endemic to Brazil, one Amazonian (only found in a small area north of Manaus), and the other from the Atlantic Forest of states of Espírito Santo and Minas Gerais (Oliveira et al. 2011).

Literature: A revision of Isertia was published by Boom (1984), which is still valid, as no additional new species have been published in this genus. Kerianthera was extensively described by Kirkbride (1985) and Delprete (1996b) and its floral features and pollination biology were studied by MarquesSouza et al. (1993) and Oliveira et al. (2011).

\section{Subfamily Ixoroideae}

2.1 Tribe Condamineeae (sensu Rova et al. 2002; Bremer \& Eriksson 2009; Kainulainen et al. 2010)

A pantropical tribe, with most genera in the Neotropics. In Brazil are present the following genera: Alseis Schott, Bathysa C. Presl, Bothriospora Hook. f., Calycophyllum DC., Capirona, Chimarrhis Jacq., Condaminea DC., Dialypetalanthus, Elaeagia Wedd., Ferdinandusa Pohl, Macrocnemum P. Browne, Parachimarrhis Ducke, Pentagonia, Pogonopus Klotzsch, Rustia Klotzsch, Semaphyllanthe L. Andersson, Simira Aubl., Sommera Schltdl., Warszewiczia Klotzsch.

Literature: A phylogeny of the tribe Condamineeae has recently been published by Kainulainen et al. (2010), which is here adopted as the reference for tribal definition and generic delimitations within the tribe. A revision of the genera Condaminea, Chimarrhis, Parachimarrhis, Pogonopus and Rustia (and several other genera not occurring in Brazil) was published by Delprete (1999). Taxonomic revisions of Brazilian species are available for Alseis (Moura 2001), Bathysa (Germano Filho 1998), Ferdinandusa (Anunciação 2005) and Warszewiczia (Pantoja 1994).

Work needed: New taxonomic revisions and comparative morphological studies are needed for Bathysa, Calycophyllum, Elaeagia, Macrocnemum, Pentagonia and Semaphyllanthe, in vision of the new generic delimitations proposed by Kainulainen et al. (2010).

\subsection{Tribe Posoquerieae}

A Neotropical tribe recently described by Delprete (in Delprete et al. 2004), with only Posoqueria Aubl. and Molopanthera Turcz., both present in Brazil. A review about the taxonomic history, morphological characters, and observations about the pollen catapult mechanism in this tribe was published by Delprete (2009).

Literature: The taxonomic revision of the Brazilian species of Posoqueria was completed by Macias (1998). A couple of new, non- zygomorphic species of Posoqueria have recently been published by Taylor \& Cortés-B. (1999) and Taylor (in Taylor $\&$ Gereau 2010b). A revision of the monotypic genus Molopanthera was published by Delprete (1999).

2.3 Tribe Henriquezieae (based on Bremer \& Eriksson, 2009, and Delprete \& Cortés-B. 2004; Cortés-B. \& Motley 2006)

A Neotropical tribe of three genera, all present in Brazil: Gleasonia, Henriquezia Spruce ex Benth., and Platycarpum, which are mostly restricted to white-sand Amazonian areas. 
Literature: A taxonomic revision of the genera of this tribe was published by Rogers (1984), which continues to be valid, as no additional species of these taxa have been described.

2.4 Tribe Sipaneeae (based on Bremer \& Eriksson 2009; Delprete \& Cortés-B. 2004)

A Neotropical tribe of about 10 genera and 50 species, with 3 species in Central America, 47 species present on the Guayana Shield, and 5 species on the Brazilian Shield. Delprete \& Cortés (2004) published a molecular phylogeny using on $t r n \mathrm{~L}-\mathrm{F}$ sequences, which clearly positioned this tribe in the Ixoroideae, closely related to the Posoquerieae, and demonstrated the monophyly of the tribe Sipaneeae. The second portion of the work of Delprete \& Cortés-B. (2004) was dedicated to the internal phylogeny of the tribe, with a molecular phylogeny using $\operatorname{trn} \mathrm{L}-\mathrm{F}$ e ITS sequences, separated and combined. Sipanea Aubl. and Limnosipanea were found in two separated clades, demonstrating that the herbaceous habit originated two times in the tribe. In the Sipaneeae, they included Chalepophyllum Hook. f., Dendrosipanea Ducke, Limnosipanea, Maguireothamnus Steyerm., Neobertiera Wernham, Sipanea e Sipaneopsis Steyerm. Due to the impossibility of obtaining valuable sequences form herbarium specimens, the genera Neblinathamnus Steyerm., Pteridocalyx Wernham and Steyermarkia Standl. were not included in the phylogenetic analysis, but where tentatively maintained in the tribe because of their morphological similarities with the other genera. According to Delprete \& Cortés-B. (2004), in Brazil are present the following genera of this tribe: Dendrosipanea, Limnosipanea, Neblinathamnus, Sipanea, and Sipaneopsis.

\subsection{Tribe Sabiceeae}

A pantropical tribe. A molecular phylogeny of this tribe was recently published by Khan et al. (2008); based on these phylogenies, they recognized four genera and about 180 species. According to their re-delimitation, Sabicea Aubl. (incl. Ecpoma K. Schum., Pseudosabicea N. Hallé, Schizostigma Arn., and Stipularia Haw., all paleotropical taxa) is the largest genus of the tribe, with about 170 species of pantropical distribution. In the Neotropics, this tribe is represented only by the genus Sabicea, with many species occurring in Brazil.

Literature: A taxonomic revision of the Neotropical species of Sabicea was recently concluded by Khan (2007).

\subsection{Tribe Mussaendeae}

A paleotropical tribe. In Brazil is only represented by several cultivated species of Mussaenda Burm. ex L.

2.7 Tribe Retiniphylleae (based on Bremer \& Eriksson 2009, and Cortés-B. et al. 2009)

A monotypic tribe, endemic to South America, represented only by Retiniphyllum Bonpl., with many species present in Brazil, mostly in white-sand areas of the Amazon Basin. The tribal position and monophyly was recently demonstrated by Cortés-B. et al. (2009)

Literature:Ataxonomic revision of Retiniphyllum was recently completed by Cortés-B. (2003).

\subsection{Tribe Ixoreae}

A pantropical tribe, with only Ixora present in the Neotropics. Ixora L. is a pantropical genus of ca. 350 species, with most of them in tropical Asia and islands of the South Pacific, ca. 37 species in continental Africa, ca. 35 species in Madagascar, and ca. 45 species in the Neotropics.

Literature: A revision of the species of Ixora present in Central and Southern Brazil was published by Delprete (2003b) and a few new species from the state of Tocantins were published by Delprete (2008a). A taxonomic revision of extra-Amazonian species of Ixora is available from Di Maio (2003).

\subsection{Tribe Vanguerieae}

A paleotropical tribe, absent in Brazil.

\subsection{Tribe Alberteae}

A paleotropical tribe, absent in Brazil.

\section{Augusta-Wendlandia-complex}

Two sister genera of uncertain taxonomic position (Rova et al. 2002; Bremer \& Eriksson 2009), related to the tribe Alberteae, of which only one species of Augusta Pohl is present in Brazil. According to Kirkbride (1997) and Delprete (1997b), Augusta is a genus of four species, divided into two subgenera. Subgenus Lindenia is composed of three species, A. rivalis (Benth.) J.H. Kirkbr., endemic to Central America, and A. austrocaledonica (Brongn.) J.H. Kirkbr. and A. vitiensis (Seem.) J.H. Kirkbr., endemic to the islands of the South Pacific. Subgenus Augusta is represented by only one species, A. longifolia (Spreng.) Rehder, endemic to Brazil, where Delprete (1997b) recognized two varieties: var. longifolia, occurring in the torrents and small 
rivers of the Cerrado Biome, and var. parviflora (Pohl) Delprete, occurring in the torrents and small rivers of the Atlantic Forest in the state of Rio de Janeiro.

Literature: A revision of the only species of Augusta present in Brazil, A. longifolia (Spreng.) Rehder, was published by Delprete (1997b).

\subsection{Tribe Bertiereae}

A monotypic tribe. Bertiera Aubl. is a genus of about 50 species mostly present in Africa, Madagascar and the Mascarene Islands, and with a few species in the Neotropics, including Brazil. The taxonomic position of this genus is not yet entirely clarified, but it seems that most contemporary rubiologists agreed to keep it in its own tribe, closely related to the Gardenieae (Bremer \& Eriksson 2009).

Literature: A worldwide survey of Bertiera was published by Robbrecht et al. (1993).

Work needed: A detailed revision of Bertiera in the Neotropics is needed, as the South American species have never been the subject of a detailed taxonomic study.

\subsection{Tribe Coffeae}

A paleotropical tribe, with several species of Coffea L. cultivated in Brazil.

\subsection{Tribe Cremasporeae}

A tribe present in Africa, Madagascar and nearby islands. Absent in Brazil.

\subsection{Tribe Octotropideae}

A tribe present in Africa, Madagascar, nearby islands, and Indomalaya. Absent in Brazil.

\subsection{Tribe Gardenieae}

According to Persson (2000a,b) and Bremer \& Eriksson (2009), this tribe is not monophyletic, and additional work remains to be done in order to detect its natural delimitation. In the phylogenies obtained by Bremer \& Eriksson (2009), members of this tribe are intermixed with members of several other tribes. Persson (2000a,b), with molecular phylogenies, palynological and anatomical data demonstrated that Alibertia A. Rich. ex DC., as traditionally recognized, should be divided into two genera: Alibertia and Cordiera A. Rich. ex DC., and that Borojoa Cuatrec. should be synonymized with Alibertia. Persson (2000a,b) also demonstrated that Ibetralia Bremek. should be synonymized with Kutchubaea Fish. ex
DC., for which he published a new combination (Persson 2005). A molecular phylogeny for Randia L. and allied genera was published by Gustafsson \& Persson (2002). Several informal groups have been proposed for the Gardenieae. In Brazil are found several genera of the "Alibertia group": Agouticarpa C.H. Perss., Alibertia (incl. Borojoa), Amaioua Aubl., Botryarrhena Ducke, Cordiera, Duroia L.f., Genipa L., Kutchubaea (incl. Ibetralia), Melanopsidium Colla, Riodocea, Sphinctanthus Benth., Stachyarrhena Hook. f., Tocoyena Aubl.; and two genera of the "Randia group": Randia and Rosenbergiodendron Fagerl.

Literature: Taxonomic revisions are available for Agouticarpa (Persson 2003), Melanopsidium (Delprete 2000), Riodocea (Delprete 1999a), Rosenbergiodendron (Gustafsson 1998), and Tocoyena (Prado 1987; Silberbauer-Gottsberger et al. 1992; Delprete 2008b).

\subsection{Tribe Paveattae}

A paleotropical tribe, absent in Brazil.

\section{Subfamily Rubioideae}

\subsection{Tribe Ophiorrhizae}

A tribe present in Tropical Asia, absent in Brazil.

\subsection{Tribe Urophylleae}

A paleotropical tribe, but of uncertain limits, as some genera have been suggested to belong to this tribe, but this has not been tested by phylogenetic studies. Bremer \& Manen (2000) and Robbrecht \& Manen (2006) positioned Amphidasya Standl. in this tribe, and it is here maintained, with the hope that future phylogenies will confirm this position. Amphidasya is a Neotropical genus, with one species, A. neblinae Steyerm., occurring in Amazonian Brazil (Serra da Neblina; Steyermark 1972).

\subsection{Tribe Perameae}

A Neotropical tribe, including only the genus Perama Aubl., with most species present in Brazil. This tribe was not included in the study by Bremer \& Eriksson (2009); however, it is here positioned near the Lasiantheae, according to the phylogenies obtained by Andersson \& Rova (1999) and Robbrecht \& Manen (2006). Bremekamp $(1934,1966)$ treated Perama as exceptional in the Rubiaceae because of absence of stipules; however, in this genus the stipules are very small or reduced to a line between the leaves of the same nodes (Delprete, pers. obs.). 
Literature: A revision of Perama for the Neotropics was published by Steyermark \& Kirkbride (1977) and additional taxa were published by Kirkbride (1980) and Steyermark (1987).

\subsection{Tribe Lasiantheae}

A tribe mostly Paleotropical, with a few species in the Neotropics. Lasianthus Jack, the largest genus of this tribe, has about 170 species occurring in the Old World and two species in the Neotropics, one in Dominican Republic and the other in Panama, but it has never been reported from South America. According to our current knowledge, this tribe is represented in Brazil only by Ronabea Aubl. Taylor (2004) recognized three species in Ronabea: R. emetica (L.f.) A. Rich. (Nicaragua to western Ecuador), R. isanae (J.H. Kirkbr.) C.M. Taylor (Amazonian northwestern Brazil), and $R$. latifolia Aubl. (from Belize to Ecuador, the Guianas to northeastern Brazil).

Literature: A revision of Ronabea was recently published by Taylor (2004).

Work needed: As Ronabea is quite similar to Psychotria L. (and it has been traditionally synonymized with), it is possible that a detailed analysis of South American species of Psychotria might detect additional taxa belonging to Ronabea

\subsection{Tribe Coussareeae}

A Neotropical tribe. Bremekamp (1951) tentatively positioned the African genus Schizocolea Bremek. within this tribe; however, in the phylogenetic studies of Rydin et al. (2008) this genus was found at an intermediate position between the Coussareae and the Psychotrieae alliance. Therefore, all the genera this tribe are present in Brazil: Coussareae Aubl., Coccocypselum P. Browne, Declieuxia Kunth, Faramea Aubl., and Hindsia Benth. Additionally, Bradea Standl. and Standleya Brade are tentatively included in the Coussareeae, based on morphological similarities and on DNA sequences of Standleya (Jardim et al., unpubl. data).

Literature: Taxonomic revisions are available for Coccocypselum (Costa 2004), Declieuxia (Kirkbride 1976, 1983, 1997), and Hindsia (Di Maio 1996). Taxonomic revisions of the Brazilian species of Coussarea and Faramea are in progress by Gomes (2003a,b), Pereira \& Barbosa (2004), and Jardim \& Zappi (2008a,b).

\subsection{Tribe Danaideae}

A Paleotropical tribe, absent in Brazil.

\subsection{Tribe Knoxieae}

A tribe present mostly in Africa and Madagascar. In Brazil is represented by Pentas lanceolata (Forssk.) Deflers, cultivated for its ornamental values.

3.8 Tribe Spermacoceae sensu lato (including Hedyotideae and Manettieae, according to Bremer \& Manen 2000; Dessein 2003; Dessein et al. 2005; Karehed \& Bremer 2007)

A pantropical tribe of about 1000 species, with a few species occurring in temperate regions of the World. The relationships between the Spermacoceae sensu stricto and the Hedyotideae have been studied by many rubiologists. Recent molecular phylogenies (Bremer \& Manen 2000; Dessein 2003; Dessein et al. 2005; Karehed \& Bremer 2007) demonstrated that this complex should be treated as a single, monophyletic tribe (including Hedyotideae and Manettieae). Also, the generic delimitations within the Spermacoceae sensu lato are the most complex and debated within the Rubiaceae, and are still far from being resolved. In a series of multidisciplinary studies Bacigalupo, Cabral and collaborators (Cabral 1991, 1993; Cabral et al. 2006; Cabral \& Bacigalupo 1997, 2000; Pire 1997; Pire \& Cabral 1992) maintained Borreria G. Mey. and Spermacoce separated, and re-established Galianthe Griseb., where they transferred many species previously positioned in Borreria. In a successive work, Bacigalupo and Cabral (1999) transferred several species from Diodia L. to Borreria, Galianthe and Diodella Samall, based primarily on fruit dehiscence types and inflorescence architecture, restricting Diodia to five species with indehiscent fruits. Govaerts (1996) in his contribution to the World Checklist of Seed Plants treated Borreria, Galianthe and Spermacoce as synonymous, and published 80 new combinations and new names in Spermacoce, mostly of Neotropical taxa. Terrell \& Wunderlin (2002) studied the seed morphology of several genera of the tribe Spermacoceae, and concluded that Borreria and Spermacoce (and Galianthe) are not sufficiently distinct to warrant taxonomic separation. In the molecular phylogenies of Dessein (2003) and Dessein et al. (2006), species with fruit types traditionally attributed to Borreria and Spermacoce were found to be intercalated within the same clades. Accordingly, Delprete et al. $(2004,2005)$ delimited Spermacoce to include species with septicidal fruits with persistent calyx, commonly dehiscent from the top (basipetally) or 
exceptionally from the bottom (acropetally; e.g., $S$. palustris (Cham. \& Schltdl.) Delprete; S. spicata (Miq.) Delprete), with both cocci dehiscent, or one dehiscent and the other indehiscent, or both of them indehiscent. A complete description of a widely delimited Spermacoce (incl. Borreria, Hemidiodia K. Schum. e Spermacoceodes Kuntze) was recently presented by Delprete \& Cortés-B. (“2006” (2007)), as adopted by Adams (in Burger \& Taylor 1993), Boom \& Delprete (2002), Delprete et al. (2005), Delprete (2007, 2010), Dessein (2003), Dessein et al. (2003, 2006a,b), Groeninckx et al. (2009a,b), Lens et al. (2009), De Vré (2000), and Vaes et al. (2006). On the other hand, the generic delimitations adopted by Cabral, Bacigalupo and collaborators (Cabral 1991, 1993; Cabral et al. 2006; Cabral \& Bacigalupo 1997, 2000; Pire 1997; Pire \& Cabral 1992), maintaining Borreria and Spermacoce separated, are still commonly adopted in several floristic treatments in the Neotropics (but not in the Paleotropics). Also, recently Salas \& Cabral (2010a) separated Tessiera DC. and Planaltina R.M. Salas \& E.L. Cabral from Staelia, based on palynological and morphological comparisons, but no dedicated phylogenetic studies were performed in order to test the monophyly of these taxa. In conclusion, following the generic concepts adopted by Bremer \& Manen (2000), Delprete et al. (2005), Delprete \& Cortés ("2006"), Delprete (2007, 2010c), Dessein (2003), Dessein et al. (2005), Groeninckx et al. (2009a,b), Lens et al. (2009), and Karehed \& Bremer (2007), in Brazil are present the following genera: Anthospermopsis (K. Schum.) J. H. Kirbr., Denscantia E.L. Cabral \& Bacigalupo, Diacrodon Sprague, Diodella Small, Diodia L., Emmeorhiza Endl., Galianthe, Leptoscela Hook. f., Manettia Mutis ex L., Mitracarpus Zucc. ex Schult. \& Schult. f., Oldenlandia L., Pentodon Hochst., Psyllocarpus Mart. ex Mart. \& Zucc., Richardia L., Spermacoce s.1. (incl. Arbulocarpus Tennat, Borreria, Bigelowia Spreng., Dasycephala Hoook. f., Diacrodon Sprague, Dichrospermum Bremek., Diodioides Loefl., Diphragmus C. Presl, Hemidiodia, Hexasepalum Bartl., Hypodematium A. Rich., Jurgensia Raf., Octodon Thonn., Paragophyton K. Schum., Spermacoceodes, Tardavel Adans.), Staelia Cham. \& Schltdl. (incl. Tessiera DC.), and Schwendenera K. Schum.

Literature: Taxonomic revisions of Brazilian species are available for Anthospermopsis (Kirkbride 1997), Bradea (Brade 1949), Denscantia (Cabral \& Bacigalupo 2001a,b), Diacrodon
(Sprague 1928), Diodella (Delprete et al. 2004; Bacigalupo \& Cabral 2006; Bacigalupo \& Cabral in Borhidi 2006), Diodia (Bacigalupo \& Cabral 1999), Galianthe (Cabral 1991, 2002, 2005; Cabral \& Bacigalupo 1997; Delprete 2010a), Leptoscela (Hooker 1873), Manettia (Macias 1998), Mitracarpus (Souza 2008; Souza et al. 2010), Psyllocarpus (Kirkbride 1979), Richardia (Lewis \& Oliver 1974), Spermacoce s.l. (regional treatments for the States of Santa Catarina (Delprete et al. 2005), São Paulo (Bacigalupo \& Cabral 2007a), Bahia (Cabral et al. 2011) and Goiás and Tocantins (Delprete 2010c)], Staelia s.l. [regional treatments for the states of Santa Catarina (Delprete et al. 2005), São Paulo (Salas 2007), and Goiás and Tocantins (Salas in Delprete 2010c), and for Paraguay (Salas \& Cabral 2010a,b)), Standleya (Brade 1932, 1949), and Schwendenera (Bacigalupo \& Cabral 2007b).

Work needed: The generic delimitations within the Spermacoceae sensu lato are still not entirely elucidated and indicate the need of producing complete molecular phylogenies with the inclusion of important Neotropical species (e.g., Spermacoce tenuior L., the type species of the genus). Much work remains to be done in order to definitely clarify the monophyly of most genera in the Spermacoceae sensu lato; therefore, it would be desirable to organize a large international, multidisciplinary team do address to these questions.

\subsection{Tribe Anthospermeae}

A tribe present in temperate regions of the world, mostly in the southern hemisphere, but absent in Brazil.

\subsection{Tribe Argostemmateae}

A tribe containing only Argostemma Wall., a Paleotropical genus of about 200 species, but absent in Brazil.

\subsection{Tribe Paederieae}

A Paleotropical tribe with only one Pantropical genus, Paederia L. According to Puff (1991a, 1991b), Paederia is a genus of 30 species, with 16 species in Asia, 12 species in Africa and Madagascar, and two species in tropical America. Puff et al. (1991a) proposed that the two American species are a long-distance dispersal event from the ancestral group present in the Old World. The two American species of Paederia are P. ciliata (Bartl. 
ex DC.) Standl. that occurs in Mexico and northern Central America, and P. brasiliensis (Hook. f.) Puff, found in South America, including Brazil. Another species of this tribe, Serissa foetida (L.f.) Lam., native of Asia, is sometimes cultivated as an ornamental in Brazil.

Literature: A taxonomic revision of the two American species of Paederia was published by Puff (1991b), and a full description of $P$. brasiliensis was published by Delprete (2010b). A full description of Serissa Commers. ex A.L. Juss. and $S$. japonica (Thunb.) Thunb. from material cultivated in Brazil, has recently been published by Delprete (2010c).

\subsection{Tribe Putorieae}

According to Bremer \& Eriksson (2009), this tribe includes only the single, widely delimited, genus Plocama Ait., distributed throughout the Paleotropics, but absent in Brazil.

\subsection{Tribe Rubieae}

A cosmopolitan tribe represented in Brazil only by Galium. Galium (incl. Relbunium (Endl.) Benth. \& Hook. f.) is a cosmopolitan genus of about 300 species, most of them occurring in temperate regions, and about 50 species in the Neotropics (Dempster \& Delprete 2004).

Literature: The South American species of Galium were revised by Dempster (1980, 1981, 1982, 1990), and the species of the state of Santa Catarina (where is found the highest diversity of this genus in Brazil) were revised by Dempster and Delprete (2004).

\subsection{Tribe Theligoneae}

This tribe includes only Theligonum, a genus of a few species occurring in Macaronesia, Mediterranean region, China and Japan. It is absent in Brazil.

\subsection{Tribe Craterispemeae}

A tribe present in Africa, Madagascar, and the Seychelles. Absent in Brasil.

\subsection{Tribe Gaertnerae}

A tribe with two genera: Gaertnera Retz., endemic to the Paleotropics, and Pagamea, endemic to the Neotropics. In Brazil are present several species of Pagamea, most of them occurring in white-sand areas.

Literature: A taxonomic revision of Pagamea has recently been completed by Vicentini (2007).

\subsection{Tribe Schradereae}

A tribe with a geographical disjunct, with two Asiatic genera (Leucocodon Gardner and Lecananthus Jack), and Schradera Vahl, present in the Neotropics, including Brazil.

\subsection{Tribe Morindeae}

A Pantropical tribe with several genera. Traditionally Morinda L. has been widely circumscribed to include Appunia Hook. f. (e.g., Steyermark 1972, 1974; Taylor \& Steyermark 2004); however, some authors preferred to keep the two taxa separated (e.g., Taylor 2001a). Razafimandinbison et al. (2009), based on their molecular phylogenies, concluded that Appunia should be kept separated from Morinda, with separate flowers in fruits in the former and partially or completely aggregated flowers and fruits in the latter. This conclusion has been followed by Parks \& McDowell (accepted) and Delprete (2009b). Accordingly, this tribe is represented in Brazil by two genera: Appunia (a Neotropical genus), and Morinda (M. citrifolia L., the famous "noni"), an Asiatic species commonly cultivated in tropical regions of the world for its medicinal properties.

Work needed: It would be highly desirable a taxonomic revision of the South American species of Appunia.

\subsection{Tribe Psychotrieae}

A Pantropical tribe with many genera, and the most speciose of the Rubiaceae. The generic delimitations within this tribe have gone through several re-arrangements according to the opinions of several rubiologists (Bremekamp 1934a,b, 1936, 1937, 1954, 1966; Steyermark 1972, 1974; Taylor 1996, 1997, 2001a,b, 2004), and continue to be far from resolved. The Psychotria complex, with nearly 2,000 species worldwide, has gone through various delimitations, and several satellite taxa have been variably excluded from or included in Psychotria. The delimitation of the genus Psychotria is still in a state of flux. The first molecular phylogeny on this tribe was published by Andersson \& Rova (1996), using rps 16 as molecular marker; this work showed that Psychotria, as delimited by Steyermark (1972, 1974), is polyphyletic, supporting the separation of some of the genera, using morphological characters, proposed by Bremekamp (1934) and Taylor (1996a) and the molecular phylogenies of Bremer (1996). In the phylogenies of Andersson \& Rova (1996), the species of Psychotria subgenus Psychotria were found on one clade, and the species of section 
Notopleura Benth. \& Hook. f. in another clade near Rudgea Salisb., and the species of subgenus Heteropsychotria in yet another clade intermixed with species of Palicourea Aubl. (indicating that the two taxa should be synonymized). Based on these results and morphological evidence, Taylor et al. (2010) and Borhidi (2011) transferred several species from Psychotria subgenus Heteropsychotria to Palicourea. These results were confirmed by Nepokroeff et al. (1999) in a study dedicated to the tribe Psychotrieae. Taylor (2001b), following the phylogenies obtained by Bremer (1996) and Nepokroeff et al. (1999), complemented by morphological data, elevated the section Notopleura to generic level, and transferred 73 Neotropical species to this genus, including many species occurring in Brazil. Andersson (2001), with a phylogenetic analysis using rps 16 molecular sequences and morphological data re-delimited Margaritopsis Sauvalle (previously restricted to the Greater Antilles) with a much wider circumscription (to include species of Chazaliella E.M.A. Petit \& Verdc., Psychotria, Chytropsia Bremek. and Readea Gillespie) with pantropical distribution. Shortly after, Andersson (2002), with a phylogenetic analysis using rps 16 molecular sequences and morphological data, re-instated the genus Carapichea Aubl., where he included three species: $C$. guianensis Aubl., C. ipecacuanha (Brot.) L. Andersson (the famous Brazilian "ipecacuanha"), and C. affinis (Standl.) L. Andersson. Following Andersson's conclusions, Delprete (2001, 2003a), transferred one more species to this genus, as $C$. ligularis (Rudge) Delprete. In conclusion, according to current generic delimitations (although not yet completely clear), in Brazil this tribe is represented by the following genera: Carapichea, Notopleura, Psychotria, Palicourea Aubl., Geophila D. Don, Margaritopsis, and Rudgea. The genera Stachyococcus Standl. and Pagameopsis Steyerm., positioned in this Psychotrieae by Robbrecht $(1988,1993)$ are tentatively maintained in this tribe, pending future phylogenetic studies to test their position.

Literature: The most complete revision of Psychotria and Palicourea species occurring from Venezuela to Central Brazil was published by Steyermark (1972), which continues to be the most important reference for northern and central Brazil. A conspectus of the genus Palicourea was published by Taylor (1997). A floristic account of Palicourea and Psychotria in the states of Goiás e Tocantins and Santa Catarina was published by Delprete (2010b) and Delprete et al. (2005), respectively.
Molecular phylogenies about the generic limits in the Psychotrieae were published by Bremer (1996), Nepokroeff et al. (1999), Andersson (2002b). Observations on the interpretation of taxonomic characters in Psychotria were published by Delprete (2001). Observations and new combinations of Carapichea species were published by Andersson (2002a) and Delprete (2001, 2003a). Two additional species of Carapichea have recently been published by Taylor (2006) and Jardim \& Zappi (2008c). A synoptic revision of the Neotropical species of Notopleura and Margaritopsis were published by Taylor (2001b, 2005). A taxonomic revision of Rudgea species from southeastern and southern Brazil has recently been published by Zappi (2003).

Work needed: As the generic delimitations within the Psychotrieae are still in a state of flux, additional molecular phylogenetic studies are needed for clarifying the monophyletic groups within this tribe. As the Psychotria complex includes about 2000 species worldwide, this project could only be realized by a team of molecular biologists, taxonomists, and field botanists devoted to the collection of necessary material. As for Brazil, considering its large geographic area and the high number of biomes, it would be desirable to have several local specialists focusing their efforts on taxonomic revisions of the members of this tribe. Additionally, as several Neotropical species of Psychotria are generally similar to Carapichea, a careful revision of Psychotria might reveal additional species to be transferred to Carapichea. As for Psychotria, additional taxonomic studied are needed in order to enhance the revision supplied in Flora brasiliensis and better understand the species occurring in Eastern Brazil and the Amazon Basin.

\section{Current status of the study of Rubiaceae diversity in Brazil}

The flora of Brazil represents one of the biggest challenges in assessing the plant diversity of our planet. The large size of the country and vast areas still to be studied, and the relentless expansion of agriculture in Brazil, place the utmost urgency in assessing and protecting its overwhelming biodiversity. A recent effort dedicated to assess the plant diversity of the country has produced the first work-on-progress checklist of native plant species (Forzza et al. 2010). This was a concerted effort of 413 taxonomists that produced a catalogue of 40,989 plants and fungi, of which 31,162 are native species of Angiosperms (and 56\% of them endemic to 
Brazil). Every species recorded was proven by a cited voucher specimen and the herbarium acronym(s) where is deposited. As part of this project, Barbosa et al. (2010) accounted for 112 genera and 1,347 species of Rubiaceae present in Brazil, of which 14 genera and 694 species (51\%) endemic to the country. Although this work was performed by a large team of specialists and with an extensive search of literature and consultation of national herbaria, many taxa will certainly be added to the list, as more herbaria and more literature will be consulted. For example, Delprete (1998) calculated (using as a working reference the Provisional Checklist of Neotropical Rubiaceae of Andersson (1992)) that there are about 115 genera and 1,600 species of Rubiaceae in Brazil, and esteemed that, including the species not yet collected (due to the vast unknown areas present in the country, especially the Amazon Region and the Atlantic Forest) and those still undescribed, there might be up to 2,000 species of this family in Brazil; however, these was just a hypothetical projection based on factors of probability related to the vast areas still botanically unknown in the country.

According to commonly accepted generic delimitations (e.g., Bremer \& Eriksson 2009, and above cited references), 15 small genera of Rubiaceae are endemic to Brazil: Anthospermopsis (1 sp.), Bradea (5 spp.), Denscantia (4 spp.), Diacrodon (1 sp.), Hindsia (11 spp.), Kerianthera (2 sp.), Leptoscela (1 sp.), Melanopsidium (1 sp.), Molopanthera (1 sp.), Planaltina (3 spp.), Psyllocarpus (8 spp.), Riodocea (1 sp.), Salzmannia (1 sp.), Schwendenera (1 sp.), and Standleya (4 spp.). More information about these genera is presented in Table 3 . The highest number of endemic genera pertaining to the tribe Spermacoceae sensu lato (incl. Hedyotideae), with 7 out of 12 genera. The low number of generic endemism is in contrast with the $56 \%$ of specific endemism. This is probably due to the fact that only a few biomes are restricted to Brazil; in fact, most genera endemic to Brazil are present in the Atlantic Forest (Restinga and tropical forest), the Caatinga, and the Campos rupestres (open field of high altitudes) of the Cerrado biome.

\section{Available keys for Rubiaceae genera}

A key for all the genera present in Brazil (and a few more that have never been found in the country) was published by Barroso et al. (1991); this key is still very helpful, although some of the generic concepts are outdated. Several keys for the identification of Rubiaceae genera are available for the following regions of Brazil: state of São Paulo
(Jung-Mendaçolli 2007), state of Santa Catarina (Delprete et al. 2004), states of Goiás and Tocantins (Delprete 2010a), and states of Mato Grosso and Mato Grosso do Sul (Delprete \& Cortés-B. 2006). In addition, several generic keys are available for local floristic treatments, as, for example, the Flora da Reserva Ducke (near Manaus, Amazonas; Taylor et al. 2007), Flora of the Pico das Almas (Chapada Diamantina, Bahia; Zappi \& Stannard 1995), Flora de Grão-Mogol, Minas Gerais (Campos et al. 2006).

\section{Future challenges on Rubiaceae systematics and floristics in Brazil}

The overwhelming vastness of its territory, the number of biomes present, and the different realities of the geographical regions of Brazil pose various challenges on the realization of projects dedicated to assessment of the biodiversity of the country. In order to convey our impressions about what is the current status and the future challenges for the study of the systematics and floristics of Brazilian Rubiaceae, our discussion will be organized according to the main regions of the country.

1. Southern Region (States of Paraná, Santa Catarina and Rio Grande do Sul) - In this region the flora is fairly well collected and the Rubiaceae are well studied. In the recent Rubiaceae account for the Flora Ilustrada Catarinense, Delprete et al. (2004, 2005 ) produced a key to genera, generic and species descriptions, illustrations, and distribution maps for 46 genera and 149 species. The collections studied cited mostly the herbarium specimens collected in the State of Santa Catarina, and many additional specimens for the two contiguous states of Paraná and Rio Grande do Sul; therefore, this publication represents a useful reference for the Rubiaceae of Southern Brazil. On the other hand, the Rubiaceae of the two bordering states have not been completely studied.

Future challenges: As the taxonomic revisions of Rubiaceae in this region is at a fairly good stage, the major challenge for this region is the continuation of field work in areas little collected, especially the highest altitudes mountain ranges and the canyons present in the states of Santa Catarina and Paraná.

2. Southestearn Region (States of Minas Gerais, Espírito Santo, Rio de Janeiro, and São Paulo) This is an extremely variable region, with many biomes, and fairly difficult terrain. In this region are present the biomes of Restinga, Atlantic Forest (both near the coast, and inland in the State of Minas Gerais), Seasonally dry forests (murundum), 
Table 3 - Table summarizing the genera endemic to Brazil, with corresponding tribe, number of species, states of occurrence, habitat, habit, and altitude. Tribes are according to the Bremer \& Eriksson (2009) and recent molecular phylogenies, as presented in the text. Tribes are abbreviated as follows: CHI-Chiococceae, COU-Coussareeae, GAR-Gardenieae, ISE-Isertieae, POS-Posoquerieae, SPESpermacoceae. Brazilian states are abbreviated as follows: AL-Alagoas, AM-Amazonas, BA-Bahia, CE-Ceará, DF-Distrito Federal, ES-Espírito Santo, GO-Goiás, MG-Minas Gerais, PB-Paraíba, PA-Paraná, PE-Pernambuco, RJ-Rio de Janeiro, RN-Rio Grande do Norte, SE-Sergipe, SP-São Paulo.

\begin{tabular}{|c|c|c|c|c|c|c|}
\hline Genera & Tribe & N. sp. & States & Habitat & Habit & Alt. (m) \\
\hline Anthospermopsis & SPE & 1 & BA & Caatinga & $\begin{array}{l}\text { subshrub } \\
(15-30 \mathrm{~cm})\end{array}$ & $50-100$ \\
\hline Bradea & $\mathrm{COU}$ & 5 & RJ, ES & $\begin{array}{l}\text { Atlantic forest } \\
\text { understory }\end{array}$ & $\begin{array}{l}\text { subshrub } \\
(40-50 \mathrm{~cm})\end{array}$ & $50-1000$ \\
\hline Denscantia & SPE & 4 & $\begin{array}{l}\text { AL, BA, } \\
\text { ES, RJ }\end{array}$ & $\begin{array}{l}\text { Atlantic forest, } \\
\text { Restinga }\end{array}$ & $\begin{array}{l}\text { subshrub or } \\
\text { scandent } \\
(0.4-4 \mathrm{~m})\end{array}$ & $20-1000$ \\
\hline Diacrodon & SPE & 1 & $\mathrm{CE}$ & Coastal vegetation & subshrub & $0-20(?)$ \\
\hline Hindsia & $\mathrm{COU}$ & 11 & $\begin{array}{l}\mathrm{BA}, \mathrm{RJ} \\
\mathrm{MG}\end{array}$ & $\begin{array}{l}\text { Atlantic forest, } \\
\text { Campos rupestres }\end{array}$ & $\begin{array}{l}\text { subshrub to } \\
\text { shrub } \\
(0.4-2 \mathrm{~m})\end{array}$ & $500-2400$ \\
\hline Kerianthera & ISE & 2 & $\begin{array}{c}\text { AM, ES, } \\
\text { MG }\end{array}$ & $\begin{array}{c}\text { Terra firme forest, } \\
\text { semideciduous } \\
\text { Atlantic forest }\end{array}$ & $\begin{array}{c}\text { tree } \\
(6-18 \mathrm{~m})\end{array}$ & $\begin{array}{l}100-200 \\
300-500\end{array}$ \\
\hline Leptoscela & SPE & 1 & $\begin{array}{l}\mathrm{AL}, \mathrm{BA} \\
\mathrm{PB}, \mathrm{PE} \\
\mathrm{RN}, \mathrm{SE}\end{array}$ & Cerrado, Caatinga & $\begin{array}{l}\text { herb } \\
( \pm 30 \mathrm{~cm})\end{array}$ & $50-1000$ \\
\hline Melanopsidium & GAR & 1 & $\begin{array}{l}\text { BA, RJ, } \\
\quad \text { ES }\end{array}$ & Restinga & $\begin{array}{l}\text { shrub to treele } \\
\quad(1.5-3 \mathrm{~m})\end{array}$ & $0-100$ \\
\hline Molopanthera & POS & 1 & $\begin{array}{l}\mathrm{ES}, \mathrm{BA}, \\
\mathrm{MG}, \mathrm{RJ}\end{array}$ & Atlantic forest & $\begin{array}{c}\text { tree } \\
(5-10(-30) \mathrm{m})\end{array}$ & $50-300$ \\
\hline Planaltina & SPE & 3 & $\begin{array}{l}\mathrm{DF}, \mathrm{GO} \\
\mathrm{MG}\end{array}$ & Cerrado & $\begin{array}{l}\text { subshrub } \\
(0.3-1.8 \mathrm{~m})\end{array}$ & $800-1500$ \\
\hline Psyllocarpus & SPE & 8 & $\begin{array}{l}\text { AM, PA, } \\
\text { RO, BA, } \\
\text { MG, GO, } \\
\text { DF }\end{array}$ & $\begin{array}{c}\text { Amazonian } \\
\text { campinas and } \\
\text { campinaranas, } \\
\text { campos rupestres }\end{array}$ & $\begin{array}{l}\text { subshrub to } \\
\text { shrub } \\
(10-120 \mathrm{~cm})\end{array}$ & $100-1600$ \\
\hline Riodocea & GAR & 1 & BA, ES & $\begin{array}{l}\text { Seasonal Atlantic } \\
\text { forest }\end{array}$ & $\begin{array}{c}\text { tree } \\
(10-15 \mathrm{~m})\end{array}$ & $50-900$ \\
\hline Salzmannia & $\mathrm{CHI}$ & 1 & $\begin{array}{l}\mathrm{AL}, \mathrm{BA} \\
\mathrm{PE}, \mathrm{RN} \\
\quad \mathrm{SE}\end{array}$ & Restinga & $\begin{array}{l}\text { shrub } \\
(1-4 \mathrm{~m})\end{array}$ & $0-70$ \\
\hline Schwendenera & SPE & 1 & $\mathrm{PA}, \mathrm{SP}$ & Forest understory & $\begin{array}{l}\text { subshrub } \\
(60-70 \mathrm{~cm})\end{array}$ & $?$ \\
\hline Standleya & $\mathrm{COU}$ & 4 & $\begin{array}{l}\text { RJ, ES, } \\
\text { BA, PA }\end{array}$ & $\begin{array}{c}\text { Atlantic Forest } \\
\text { understory }\end{array}$ & herb & $50-1000$ \\
\hline
\end{tabular}


and alluvial forest of the Rio Doce, humid forests of high elevation (states of São Paulo and Rio de Janeiro), campos de altitude (Rio de Janeiro), and Cerrado and Campo rupestre (Minas Gerais). The state least collected, where is expected a high degree of endemism, and where is potentially present the highest number of undescribed Rubiaceae species in this region is the State of Espírito Santo (Delprete, pers. obs.). At the same time, in the State of Minas Gerais is found the highest number of endemic Angiosperm species (Forzza et al. 2010), mostly because is where several biomes converge and intergrade, and where are found several mountain ranges (e.g., Cadeia do Espinhaço). Assessing and conserving plant diversity in Minas Gerais is of the utmost urgency, due to the rapid destruction of the environment, mostly due to Eucalyptus plantations and mineral exploration.

Literature: The most complete Rubiaceae treatment of this region is that published for the Flora Fanerogâmica do Estado de São Paulo, produced by a team of 20 botanists and coordinated by Jung-Mendaçolli (2007). The treatment includes a key to genera, generic and species descriptions, and selected illustrations of 48 genera and 254 species. Only a few of the collections studied (only from the state of São Paulo) are cited in full for each species, and the remainder is summarized in an index of exsiccatae at the end of the treatment.

Future challenges: Because of the above explained reasons, the biggest challenges for assessing the Rubiaceae diversity of this region are field collections and floristic treatments for the states of Minas Gerais, Espírito Santo, and Rio de Janeiro. As indicated above, the State of Espírito Santo is the area that has the potential to provide the highest number of undescribed Rubiaceae taxa, in this region. The delta of the Rio Doce is a unique area of the Atlantic Coast, where the mountain ranges that run parallel to the coast in this region are much lower, leaving a unique area in terms of climate and soil types, which is still poorly studied. As the Rubiaceae diversity of this region remains imperfectly know, field collections to be realized by family specialists are highly recommended. The second challenge for Rubiaceae taxonomists is to engage in taxonomic revisions of groups particularly speciose in this region, as the tribes Gardenieae, Guettardeae, Psychotrieae, and Spermacoceae.

3. Central-Western Region (States of Goiás, Mato Grosso, Mato Grosso do Sul, and Distrito Federal) - The states of Mato Grosso and Mato Grosso do
Sul together represent about 14\% of the Brazilian territory. Three major biomes are present in these two states: Cerrado, Pantanal, and the Amazon Basin. Although several expeditions have been made in the Amazonian portion of Mato Grosso, this region remains botanically poorly known, mostly due to the difficulty of access. Within this area, many little-explored white sand areas are also present, which are renowned to be center of diversity for many endemic Rubiaceae species. The Amazonian forests of this state are under the relentless advancement of timber exploitation and extensive soya plantations, and it is probably subject to the fastest destruction rate of any Brazilian state within the Amazon Basin.

Literature: A synopsis of the Rubiaceae of the States of Mato Grosso and Mato Grosso do Sul has recently been published by Delprete \& Cortés-B. (2006), which accounts for 68 genera and 269 species. In this synopsis are available a key to genera, full description of all genera, and a list of all the species with corresponding full synonymy (but no specimens cited).

The second portion of the floristic project initiated by J.A. Rizzo (Federal University of Goiás, Goiânia, Goiás), was the coordination of a floristic series, Flora dos Estados de Goiás e Tocantins - Coleção Rizzo, which today counts with the publications of 40 volumes. As part of this series, the Rubiaceae treatment for the States of Goiás and Tocantins has been recently contributed by Delprete (2010a,b,c), with several collaborators, that counted on the study of about 60,000 herbarium specimens collected in both states, and preserved in 26 Brazilian and international herbaria. This treatment, of 61 genera and 245 species, includes a key to genera, keys, full descriptions and notes about the conservation status of all species, full citation of all the specimens studied, and illustrations of representative species. In the introduction is also presented a detailed discussion of the areas that should be prioritized for botanical collections and conservation.

In the series called Flora do Distrito Federal, coordinated by T.B. Cavalcanti (EMBRAPA, Brasília, Distrito Federal), have been published the floristic treatments of many Angiosperm families (the eight volume was published in 2010). The treatment dedicated to the family Rubiaceae is at the final stage, and is being contributed by Delprete and collaborators.

An extensive publication on the ecology, vegetation, and floristics of the Cerrado Biome has recently been coordinated by Sano et al. (2008). 
In this multi-authored work, it was presented an updated checklist of the Cerrado Biome, with 1,452 genera and 11,238 species of Angiosperms. In this checklist, the Rubiaceae figured as the seventh most diverse family of this biome, with 60 genera and 376 species, after the Leguminosae (108 genera, 1,174 spp.), Asteraceae (155 genera, 1,074 spp.), Orchidaceae (121 genera, 666 spp.), Poaceae (91 genera, 510 spp.), and Eriocaulaceae (7 genera, 473). This low species number of Rubiaceae in the Cerrado Biome is not surprising, as the high diversity of this family is usually found in moist environments, as the Atlantic forest and the Amazon Basin.

Future challenges: For the reasons explained above, the northern portion of the state of Mato Grosso merits the highest priority and urgency for the realization of botanical collections, due to the relentless expansion of agriculture. Most likely, many species present in this area have been destroyed before being known to science. The Rubiaceae synopsis of Mato Grosso and Mato Grosso do Sul (Delprete \& Cortés-B. 2006) is only the first step towards the study of Rubiaceae diversity of the region; certainly, future collections in the northern portion of Mato Grosso will add more taxa to this list.

4. Northeastern Region (States of Maranhão, Piauí, Ceará, Rio Grande do Norte, Paraíba, Pernambuco, Alagoas, Sergipe, and Bahia)

The northeastern region of Brazil is a mosaic of different realities in terms of conservation of the natural environment, number of botanical collections, and local concentration of botanists. The eastern portion of the state of Maranhão, the floristic domain of the famous peri-Amazonian forest, and where a high Rubiaceae diversity was certainly present, is largely destroyed (Delprete, pers. obs.) due to extensive lumbering. The devastation in this area is so great that many local sawmills had to close down due to lack of available timber. In other words, the peri-Amazonian forest once presents in Maranhão, a repository of a unique floristic composition, and certainly with a high percentage of Rubiaceae, has been vastly destroyed before being studied. The states of Piauí, Ceará, Rio Grande do Norte, Paraíba, Alagoas, and Sergipe share a common situation in terms of a low number of local botanists and paucity of botanical collections. However, a better knowledge on the plant diversity is available for the State of Paraíba, and a few studies on the local flora are published or in progress (Pereira \& Barbosa (2004, 2006). The state with the highest collection density, and therefore with a better Rubiaceae representation, of the region is that of Pernambuco, due to the historical number of institutions and botanists present in the city of Recife. The State of Bahia presents a different reality from the remainder of the states of northeastern Brazil, mostly for high number of institutions and local botanists. The Botany Department of the State University of Feira de Santana (UEFS) has gone through a rapid evolution in terms of number of botanists, research and botanical collections, since the arrival of A.M. Giulietti, the coordinator of the Botany program of this institution. The UEFS has an active botanical graduate program, and has recently trained several Rubiaceae graduate students (under the supervision of D. Zappi, Kew Botanic Gardens, England) that contributed considerably to the knowledge of the Rubiaceae of Brazil.

Literature: A floristic treatment of the Rubiaceae of the Pico das Almas (Chapada Diamantina, Brazil) was published by Zappi \& Stannard (1995) that included key to genera, generic and specific descriptions, and specimens cited for 25 genera and 46 species. A Rubiaceae checklist of the brejos (wet mountain slopes) of the state of Pernambuco was published by Zappi et al. (1998). Preliminary Rubiaceae checklists for Northeastern Brazil were published by Zappi \& Nunes (2000, 2002).

Future challenges: The main challenge for the entire northeastern region is the continuation of botanical collections throughout the region, and the formation of local Rubiaceae specialists, as most states of this region are still far from being botanically known. Specifically for the Rubiaceae, it is extremely important to start collecting in the forest remnants of the peri-Amazonian in the state of Maranhão, where is mostly likely to find a high diversity of Rubiaceae (and many other plant families). Additional areas of collections, which are significant centers of Rubiaceae diversity, are the wet mountain slopes (locally called "brejos") of this region. Other additional biomes present in the region and that deserve the highest priority in terms of botanical collecting and conservation are the much endangered Restinga and Atlantic forest, both of them under threat of complete destruction because of high human pressure. In both of these last biomes the Rubiaceae represent one of the most diverse families, and these are the localities where is most likely do discovered undescribed species. In order to assure the continuation of Rubiaceae studies in this region, it is highly desirable the formation of master and doctoral students with 
subjects focusing on members tribes particularly complex in the northeastern region of Brazil, as the Psychotrieae, Guettardeae and Spermacoceae.

5. Northern Region (States of Amapá, Pará, Tocantins, Roraima, Amazonas, Acre, and Rondônia) - The states of northern Brazil occupy the majority of the Amazon Basin. This region represents the greatest challenge in assessing the total biodiversity in Brazil. The Amazonian Biome is the largest in Brazil (61\% of Brazil surface, and one-third of the tropical rainforest of the planet), and has the lowest number of botanists per unit surface. In this biome, the Rubiaceae represents one of the largest families (Taylor et al. 2007; Delprete \& Taylor 2008), and one of the most important, in terms of richness, abundance, and presence at all vegetational layers of the forest.

All the states of the Amazon Basin share a similar reality in terms of underrepresentation of botanical collections (in terms of collection density) and presence of very few local botanists. The state of Pará, one of the two giant states of Amazonian Brazil, with a surface of about 1.2 million $\mathrm{km}^{2}$, houses two large herbaria in the oldest institutions of the Brazilian Amazon, the Museu Goeldi and the Instituto Agronômico do Norte (IAN, now part of the EMBRAPA Amazônia Oriental). The two herbaria together preserve a total of 346,000 specimens [data according to Index herbariorum (see Thiers, continuously updated); percentage of Rubiaceae unknown], which is the highest number of herbarium specimens of any Amazonian state. Nevertheless, this is far from being representative of the local flora, corresponding to a collection density of 0.28 collections $/ \mathrm{km}^{2}$, as the northern portion of the state remains poorly collected.

Amapá is one of the least collected states of the Brazilian Amazon. The state is entirely within the Amazon Region (and the Guyana Shield), mostly covered by tall lowland forest, and with a central region of Amazonian savannas (opens fields, seasonally or permanently inundated). A few botanical expeditions in Amapá were organized in the XX century by the Museu Goeldi, the New York Botanical Garden, and the IEPA(Instituto de Estudos e Pesquisas do Estado do Amapá). Nowadays, local institutions suffer form lack of botanical personnel and at the only local herbarium (HAMAB) are preserved 9,000 specimens (ca. 500 Rubiaceae specimens; Delprete, pers. obs.). Additionally, the natural environment of central portion of the state is been destroyed by extensive Eucalyptus plantations.

The state of Tocantins is also botanically little-collected. The northern portion of the state is part of the Amazon Basin, and the forests present at river margins are composed by a significant number of Amazonian species. Aside from this, the forests of the northern portion of this state are located in an area of transition between the Cerrado Biome and Amazonian Basin, and therefore with a floristic composition with elements from both biomes, as well as species that are unique to this vegetation. The only herbarium present in the state (HTO) houses 9,700 specimens (data according to Thiers continuously updated), which is well below from being representative of the local flora.

Roraima shares the same reality of Amapá, by being a small state, and the local herbarium (MIRR) houses about 8,000 specimens (ca. 300 Rubiaceae specimens). The paucity of botanists and the difficulty of access to the remote areas of the state are the main factors that hampered the botanical collections in this state. The northern limit of the state (and the northernmost point in Brazil) is an extremely interesting area for botanical collections, and even more for Rubiaceae, because it is part of the Tepui region (Guayana Highlands).

Amazonas is the second giant state of the Brazilian Amazon, with a surface of about 1.6 million $\mathrm{km}^{2}$ (the largest Brazilian state). The main herbarium of the state, housed at the INPA (Instituto Nacional de Pesquisas da Amazonia), counts with a considerable number of botanists and preserves about 205,000 specimens (according to Thiers continuously updated). This state shares the same realities of Pará, because of its huge size and the insufficient botanical collections, due to the difficulties of reaching the remote areas.

Rondônia shares the same reality of Roraima and Amapá, by being a small state, with a few local botanists and even fewer botanical collections, with respect to other Amazonian states. The sole local herbarium, housed at Faculdade São Lucas, preserves about 5,200 specimens (HFSL; data according to Thiers continuously updated).

Acre is the Amazonian state of Brazil with the highest density of botanical collections, in collaboration with many members of the Universidade Federal do Acre and the New York Botanical Garden. The signature of official agreement between the two institutions was made in 1991, and the active team started the botanical explorations shortly after, producing a considerable amount of herbarium specimens. A subsequent successful program, called "Mobilizing Taxonomic Specialists", coordinated the botanical collections and herbarium identifications of specialists of 
the largest plant families of Acre, from 2001 to 2005 , and raised the overall index of collection density from 13 to 16 collections/ $\mathrm{km}^{2}$. However, as it was well put the Daly \& Silveira (2008, p. 77) "Sadly, floristic work in Amazonian Brazil decreased dramatically overall after the end of the Projeto Flora Amazônica, and the Mobilizing Taxonomic Specialists project constituted one of the very few ongoing floristic efforts in the 5,217, $423 \mathrm{~km}^{2}$ of the Brazilian Amazon. Considering the accelerated pace of change in forest cover and the regional climate, we urge national and international programs of collaborative research to help multiply floristic research programs, generating information and leading to conclusions essential for effective conservation and management of Amazonia's plant resources." Nowadays, at the herbarium of the Federal University of Acre are stored about 30,000 specimens, which is considerably representative of the flora of the state, although still far from complete.

Literature: A floristic treatment of the Rubiaceae for the Flora da Reserva Ducke was published by Taylor et al. (2007), accounting for 36 genera and 99 species, with keys and descriptions for genera and species, and citation of specimens studied; it might seems incredible, but this is most complete floristic treatment of this family for the whole Brazilian Amazon. A checklist of the Rubiaceae for the state of Acre was recently published by Delprete \& Taylor (2008), where is recorded as the second most diverse family, with 62 genera and 243 species, after the Leguminosae sensu lato (86 genera, $327 \mathrm{spp}$.). A floristic treatment of the Rubiaceae of the resting $a$ vegetation of the reserve of Algodoal/Maiandeua was recently published by Margalho et al. (2009). The Rubiaceae treatments for the Flora of the Guyana Highlands contributed by Steyermark $(1964,1965,1967,1972)$ and that of the Flora of the Venezuelan Guyana by Taylor et al. (2004) are the most complete references for this family in the Brazilian Amazon.

Future challenges: The study of the floristic diversity in the Amazon basin represents the greatest challenge for the study of the Brazilian vegetation, especially for a large family as the Rubiaceae. This goal could be accomplished only by a large team of specialists. As pointed out above, the two major limiting factors for this region are the paucity of local botanists and the difficulty of access to remote areas. For these reasons, it becomes extremely important the formation of local botanists at all levels, and therefore the training of young specialists in Rubiaceae projects on taxa particularly speciose and/or taxonomically complex in the Amazon Basin. Potential subjects for master and doctoral projects on Rubiaceae groups occurring in the Brazilian Amazon are the following:

1) Tribe Guettardeae: Chomelia and Guettarda;

2) Tribe Condamineeae: Bathysa, Calycophyllum, Elaeagia, Macrocnemum, Pentagonia, and Semaphyllanthe (according to the new generic delimitations proposed by Kainulainen et al. 2010);

3) Tribe Ixoreae: Ixora;

4) Tribe Bertiereae: Bertiera;

5) Tribe Coussareae: Coussarea and Faramea;

6) Tribe Spermacoceeae: Spermacoce sensu lato (incl. Borreria);

7) Tribe Morindae: Appunia;

8) Tribe Psychotrieae: Carapichea, Notopleura, Psychotria, Palicourea, Geophila, and Margaritopsis.

It is our hope that this work will help promoting systematic, taxonomic and floristic studies of Rubiaceae in Brazil, by pointing out complex groups in need of taxonomic revisions, and particular regions where Rubiaceae studies are still lacking.

As in most tropical regions of the planet, floristic assessments rely heavily on field collections and taxonomic treatments. Monographic treatments contribute towards the clarification of taxonomic units (species) and the information about their geographic distribution, ecology and conservation biology. Nowadays, as we are going through the most important biodiversity crisis known to humanity, the number of taxonomists has been diminishing during the last decades. Because of the combination of massive destruction of the ecosystems and the fast diminishing of taxonomists, many species actually disappear before being known, a process known as the "anonymous extinction" by Campbell (1989). After their extinction, the role of these species in the equilibrium of the ecosystem where they use to live will never be known. For this reason, the disappearing of taxonomists has been called "the secondary crises of biodiversity" (Mori 1992). As the family Rubiaceae is so extremely diverse, present in most Brazilian biomes, and in most vegetational layers, the information supplied by taxonomic treatments represents an important set of data that could used in ecological studies and in the assessments of phytosociology and conservation 
biology (Miatelo 2008; Miatelo et al. 2010). At the end of our survey, it became obvious that the region of Brazil that is in most need of local specialists, field work and taxonomic studies of the family Rubiaceae is the Amazon Basin; therefore, it is of cardinal importance the formation of a new generation of local Rubiaceae specialists in order to expand and assure the continuation of the study of this extremely complex family.

\section{References}

Achille, F.; Motley, T.J.; Lowry P.P. \& Jéremie, J. 2006. Polyphyly in Guettarda L. (Rubiaceae, Guettardeae) based on nrDNA ITS sequence data. Annals of the Missouri Botanical Garden 93: 103-121.

Amaya-Worms, A. 2008. The genus Malanea (Guettardeae, Rubiaceae) in Venezuela. In: Ochoterena, H. et al. (eds.). IV International Rubiaceae (Gentianales) Conference. Scripta Botanica Belgica 44: 20.

Amaya-Worms, A. \& Delprete, P.G. 2010. The genus Malanea Aubl. (Guettardeae, Rubiaceae) in the Guianas (Guyana, Suriname and French Guiana). In: Fifth International Rubiaceae and Gentianales Conference - Biodiversity in the light of Historical Information. The Royal Swedish Academy of Sciences, Stockholm University, Stockholm. P. 21.

Anderson, C.L.; Rova, J. H. E. \& Andersson, L. 2001. Molecular phylogeny of the tribe Anthospermeae (Rubiaceae): systematic and biogeographic implications. Australian Systematic Botany 14: 231-244.

Andersson, L. 1993. Rubiaceae: 162 (22): Introduction, Anthospermeae. In: Harling, G.W. \& Andersson, L. (eds.). Flora of Ecuador 47. University of Goteborg. Pp. 3-17.

Andersson, L. 1994. Rubiaceae: 162 (22): Cinchoneae. In: Harling, G.W. \& Andersson, L. (eds.). Flora of Ecuador 50. University of Goteborg. Pp. 3-82.

Andersson, L. 1995. Tribes and genera of the Cinchoneae complex (Rubiaceae). Annals of the Missouri Botanical Garden 82: 409-427.

Andersson, L. 1996. Circumscription of the tribe Isertieae (Rubiaceae). Opera Botanica Belgica 7: 139-164.

Andersson, L. 1997. Synopsis of the genus Ladenbergia (Rubiaceae). Nordic Journal of Botany 17: 255-299.

Andersson, L. 2001. Peratanthe is a synonym of Nertera (Rubiaceae, Anthospermeae). Brittonia 52: 351-353.

Andersson, L. 2002a. Re-establishment of Carapichea (Rubiaceae, Psychotrieae). Kew Bull. 57: 363-374.

Andersson, L. 2002b. Relationships and generic circumscriptions in the Psychotria complex (Rubiaceae, Psychotrieae). Systematics and Geography of Plants 72: 167-202.
Andersson, L. \& Antonelli, A. 2005. Phylogeny of the tribe Cinchoneae (Rubiaceae), its pposition in Cinchonoideae, and description of a new genus, Ciliosemina. Taxon 54: 17-28.

Andersson, L. \& Persson, C. 1991. Circumscription of the tribe Cinchoneae (Rubiaceae) - A cladistic approach. Plant Systematics and Evolution 178: 65-94.

Andersson, L. \& Rova, J.H.E. 1999. The rps 16 intron and the phylogeny of the Rubioideae (Rubiaceae). Plant Systematics and Evolution 214: 161-186.

Andreasen, K.; Baldwin, B.G. \& Bremer, B. 1999. Phylogenetic utility of the nuclear rDNA ITS region in subfamily Ixoroideae (Rubiaceae): Comparisons with cpDNA rbcL sequence data. Plant Systematics and Evolution 217: 119-135.

Andreasen, K. \& Bremer, B. 1996. Phylogeny of the subfamily Ixoroideae (Rubiaceae). Opera Botanica Belgica 7: 119-138.

Andreasen, K. \& Bremer, B. 2000. Combined phylogenetic analysis in the Rubiaceae-Ixoroideae: morphology, nuclear, and chloroplast DNA data. American Journal of Botany 87: 1731-1748.

APG - Angiosperm Phylogeny Group. 1998. An ordinal classification for the families of flowering plants. Annals of the Missouri Botanical Garden 85: 531-553.

APG - Angiosperm Phylogeny Group. 2003. An update of the Angiosperm Phylogeny Group classification for the orders and families of flowering plants: APG II. Botanical Journal of the Linnaean Society 141: 399-436.

APG - Angiosperm Phylogeny Group. 2009. An update of the Angiosperm Phylogeny Group classification for the orders and families of flowering plants: APG III. Botanical Journal of the Linnean Society 161: 105-121.

Anunciação, E.A. 2005. Revisão taxonômica de Ferdinandusa (Rubiaceae). Doctoral Thesis. Universidade de São Paulo, São Paulo. 200p.

Bacigalupo, N.M. \& Cabral, E.L. 1999. Revisión de las espécies americanas del género Diodia (Rubiaceae, Spermacoceae). Darwiniana 37: 153-165.

Bacigalupo, N.M. \& Cabral, E.L. 2007a. Borreria. In: Wanderley, M.G.L. (coord.). Flora fanerogâmica do estado de São Paulo. Vol. 5. Instituto de Botânica, São Paulo. Pp. 276-285.

Bacigalupo, N.M. \& Cabral, E.L. 2007b. Schwendenera. In: M.G.L. Wanderley (coord.). Flora fanerogâmica do estado de São Paulo. Vol. 5. Instituto de Botânica, São Paulo. P. 434, fig. 24.

Backlund, M.; Oxelman, B. \& Bremer, B. 2000. Phylogenetic relationships within the Gentianales based on $n d h \mathrm{~F}$ and $r b c \mathrm{~L}$ sequences, with particular reference to the Loganiaceae. American Journal of Botany 87: 1029-1043.

Baillon, H.E. 1880. Rubiacées-Dipsacacées. Histoire Naturelle des Plantes 7. L. Hachette et Cie., Leipzig, Paris. Pp. 257-503. 
Barbosa, M.R.; Zappi, D.; Taylor, C.M.; Cabral, E.L.; Jardim, J.G.; Pereira, M.S.; Calió, M.F.; Pessoa, M.C.R.; Salas, R.; Souza, E.B.; Di Maio, F.R.; Macias, L.; Anunciação E.A. \& Germano Filho, P. 2010. Rubiaceae. In: Forzza, R. et al. (orgs.). Lista de espécies da flora do Brasil. Vol. 2. Jardim Botânico do Rio de Janeiro, Rio de Janeiro. Pp. 1545-1591.

Barroso, G.M.; Peixoto, A.L.; Ichaso, C.L.F.; Costa, C.G.; Guimarães, E.F. \& Lima, A.C.L. 1991. Rubiaceae. In: Sistemática de angiospermas do Brasil. Vol. 3. Universidade Federal de Viçosa, Impresa Universitária, Viçosa. Pp. 189-229.

Boom, B.M. 1984. A revision of Isertia (Isertieae: Rubiaceae). Brittonia 36: 425-454.

Boom, B.M. \& Delprete, P.G. Rubiaceae. 2002. In: Mori, S.A. et al. (eds.). Guide to the vascular plants of central French Guiana. Part 2. Dicotyledons. Memoirs of the New York Botanical Garden 76: 606-649.

Borhidi, A. 2006. Rubiáceas de México. Akadémia Kiadó, Budapest. 512p.

Borhidi, A. 2011. Transfer of the Mexican species of Psychotria subgen. Heteropsychotria to Palicourea based on morphological and molecular evidences. Acta Botanica Hungarica 53(3-4): 241-250.

Brade, A.C. 1932. Standleya. Arquivos do Museu Nacional de Rio de Janeiro 34: 119-121.

Brade, A.C. 1949. Rubiaceae. In: Contribuição para o conhecimento da flora do estado do Espirito Santo. II. Espécies nova das famílias Orchidaceae, Rubiaceae e Gentianaceae. Arquivos do Jardim Botânico de Rio de Janeiro 9: 14-18, est. 5-11.

Bremekamp, C.E.B. 1934a. Rubiaceae. In: Pulle, A. (ed.). Flora of Suriname 4: 113-298.

Bremekamp, C.E.B. 1934b. Notes on the Rubiaceae of Surinam. Recueil des Travaux Botaniques Néerlandais 31: 248-308.

Bremekamp, C.E.B. 1936. Additional notes on the Rubiaceae of Surinam. Recueil des Travaux Botaniques Néerlandais 33: 705-715.

Bremekamp, C.E.B. 1937. Rubiaceae (additions and corrections). In: Pulle, A. (ed.). Flora of Suriname 4: 475-491.

Bremekamp, C.E.B. 1940. On Urophyllum Wall. (Rubiaceae) and its nearest allies. Recueil Trav. Bot. Neerl. 37: 171-197.

Bremekamp, C.E.B. 1951. Schizocolea linderi (Hutch. et Dalz.) Brem. Hooker's Icones Plantarum 35: ad tab. 3482 .

Bremekamp, C.E.B. 1954. Les sousfamilles et les tribus des Rubiaceae. Huitièm Congrès International de Botanique, Paris. Pp. 113-114.

Bremekamp, C.E.B. 1966. Remarks on the position, the delimitation, and the subdivision of the Rubiaceae. Acta Botanica Neerlandica 15: 1-33.
Bremer, B. 1987. The sister group of the Paleotropical tribe Argostemmateae: A redifined Neotropical tribe Hamelieae (Rubiaceae, Rubioideae). Cladistics 2: 55-71.

Bremer, B. 1992. Phylogeny of the Rubiaceae (Chiococceae) based on molecular and morphological data - Useful approaches for classification and comparative ecology. Annals of the Missouri Botanical Garden 79: 380-387.

Bremer, B. 1996. Phylogenetic studies within Rubiaceae and relationships to other families based on molecular data. Opera Botanica Belgica 7: 33-50.

Bremer, B.; Andreasen, K. \& Olsson, D. 1995. Subfamilial and tribal relationships in the Rubiaceae based on $r b c \mathrm{~L}$ sequence data. Annals of the Missouri Botanical Garden 82: 383-397.

Bremer, B. \& Eriksson, O. 1992. Evolution of fruit characters and dispersal modes in the tropical family Rubiaceae. Biological Journal of the Linnean Society 47: 79-95.

Bremer, B. \& Eriksson, O. 2009. Time tree of Rubiaceae: phylogeny and dating the family, subfamily, and tribes. International Journal of Plant Science 170: 766-793.

Bremer, B. \& Jansen, R.K. 1991. Comparative restriction site mapping of chloroplast DNA implies new phylogenetic relationships within the Rubiaceae. Amerian Journal of Botany 78: 198-213.

Bremer, B.; Jansen, R.K.; Oxelman, B.; Backlund, M.; Lantz, H. \& Kim, K.-J. 1999. More Characters and more taxa for a robust phylogeny - case study from the coffee family (Rubiaceae). Systematic Biology 48: 413-435.

Bremer, B. \& Manen, J.-F. 2000. Phylogeny and classification of the subfamily Rubioideae. Plant Systematics and Evolution 225: 43-72.

Bremer, B. \& Thulin, M. 1998. Collapse of Isertieae, reestablishment of Mussaendeae, and a new genus of Sabiceeae (Rubiaceae); phylogenetic relationships based on $r b c \mathrm{~L}$ data. Plant Systematics and Evolution 211: 71-92.

Burger, W. \& Taylor, C.M. 1993. Family 202 Rubiaceae. In: Burger, W. (ed.). Flora costaricensis. Fieldiana, Botany, new series 33: 1-333.

Cabral, E.L. 1991. Rehabilitación del género Galianthe (Rubiaceae). Boletin de la Sociedad Argentina de Botanica 27: 235-249.

Cabral, E.L. 1993. Novedades em Galianthe (Rubiaceae). Bonplandia 7: 1-29.

Cabral, E.L. 2002. Revisión del género Galianthe (Rubiaceae). Doctoral dissertation. Universidad del Nordeste, Corrientes. 317p.

Cabral, E.L. 2005. Notes on Galianthe (Spermacoce, Rubiaceae) in the Bolivian flora. Brittonia 57: 141-149. 
Cabral, E.L. \& Bacigalupo, N.M. 1997. Revisión del género Galianthe subg. Ebelia stat. nov. (RubiaceaeSpermacoceae). Annals of the Missouri Botanical Garden 83: 857-877.

Cabral, E.L. \& Bacigalupo, N.M. 2000. Novedades taxonômicas em Galianthe y Borreria (RubiaceaeSpermacoceae). Bonplandia 10: 119-128.

Cabral, E.L. \& Bacigalupo, N.M. 2001a. Scandentia, nuevo género de Rubiaceae-Spermacoceae. Darwiniana 39: 29-41.

Cabral, E.L. \& Bacigalupo, N.M. 2001b. Denscantia, nuevo nombre en reemplazo de Scandentia (Rubiaceae-Spermacoceae). Darwiniana 39: 353.

Cabral, E.L.; Mari, E. \& Pire, S.M. 2006. Borreria secc. Pseudodiodia (Rubiaceae), aportes taxonômicos y palinológicos. Bonplandia 15: 79-90.

Cabral, E.L.; Miguel, L.M. \& Salas, R.M. 2011. Dos especies nuevas de Borreria G. Mey. (Rubiaceae), sinopsis y clave de las especies para Bahia, Brasil. Acta Botanica Brasilica 25: 255-276.

Campbell, D.G. 1989. The importance of floristic inventory in the tropics. In: Campbell, D.G. \& Hammond, H.D. (eds.). Floristic inventory of tropical countries. The New York Botanical Garden, New York. Pp. 5-30.

Campos, M.T.V.A.; Zappi, D.; Calió, M.F. \& Pirani, J.R. 2006. Flora de Grão-Mogol, Minas Gerais: Rubiaceae. Boletim de Botânica da Universidade de São Paulo 24: 41-67.

Chase, M.W. et al. 1993. Phylogenetics of seed plants: an analysis of nucleotide sequences from the plastid gene $r b c L$. Annals of the Missouri Botanical Garden 80: 528-580.

Cortés-B., R. 2003. Systematics and biogeography of Retiniphyllum (Rubiaceae). Ph.D. Dissertation. City University of New York, New York. 408p.

Cortés-B., R. \& Motley, T.J. 2006. Systematics of the tribe Henriquezieae (Ixoroideae, Rubiaceae) and allies. Oral presentation. Programme and abstracts. Third International Rubiaceae Conference, Leuven.

Cortés-B., R.; Delprete, P.G. \& Motley, T.J. 2009. Phylogenetic placement of the tribe Retiniphylleae among the sufamily Ixoroideae (Rubiaceae). Annals of the Missouri Botanical Garden 96: 61-67.

Costa, C.B. 2004. Revisão taxonômica de Coccoypselum (Rubiaceae). Doctoral Thesis. São Paulo University, São Paulo. 151p.

Cronquist, A. 1981. An integrated system of classification of flowering plants. Columbia University Press, New York. 1262p.

Daly, D.C.; Silveira, M. et al. "2008” [2009]. Primeiro Catálogo da Flora do Acre, Brasil/First Catalogue of the Flora of Acre, Brazil. EDUFAC, Rio Branco. $555 \mathrm{p}$.

Darwin, S.P. 1976. The subfamilial, tribal and subtribal nomenclature of the Rubiaceae. Taxon 25: 595-610.
Delprete, P.G. 1996a. Evaluation of the tribes Chiococceae, Condamineeae and Catesbaeeae (Rubiaceae) based on morphological characters. Opera Botanica Belgica 7: 165-192.

Delprete, P.G. 1996b. Notes on the taxonomic position of the monotypic Brazilian genus Kerianthera (Rubiaceae). Opera Botanica Belgica 7: 271-275.

Delprete, P.G. 1997a. Revision and typification of Brazilian Augusta (Rubiaceae, Rondeletieae), with ecological observation on riverine vegetation of Cerrado and Atlantic Forest. Brittonia 49: 487-497.

Delprete, P.G. 1997b. Notes on calycophyllous Rubiaceae. Part II. Morphological comparisons of the genera Bathysa and Schizocalyx. Brittonia 49: 480-486.

Delprete, P.G. 1997c. Systematics and floristics of Neotropical Rubiaceae. $48^{\circ}$ Congresso Nacional de Botânica, Crato. Resumos. Pp. 246-347.

Delprete, P.G. 1998a. Notes on calycophyllous Rubiaceae. Part III. Systematic position of the monotypic Mexican genus Cosmocalyx and notes on the calycophyll development. Brittonia 50: 309-317.

Delprete, P.G. 1998b. Notes on calycophyllous Rubiaceae. Part IV. The monotypic Brazilian genus Blandibractea Wernham is a Simira (Rondeletieae). Brittonia 50: 318-323.

Delprete, P.G. 1998c. Notes on Calycophyllum DC. (Rubiaceae) and Pisonia L. (Nyctagynaceae) in Paraguay. In: Ramella, L. \& Perret, P. (eds.). Notulae ad Floram paraquaiensem 68. Candollea 53: 459-462.

Delprete, P.G. 1998d. Sinopse dos gêneros de Rubiaceae do Brasil. 49 ${ }^{\circ}$ Congresso Nacional de Botânica, Salvador. Resumos. Pp. 85-86.

Delprete, P.G. 1999a. Riodocea (Rubiaceae, Gardenieae), a new genus from the Bahian Hylea, Brazilian Atlantic forest. Brittonia 51: 15-23.

Delprete, P.G. 1999b. The status of monografic and floristic studies of Neotropical Rubiaceae, with emphasis on the Flora of The Guianas. Flora of The Guianas Newsletter 12: 11-13.

Delprete, P.G. 1999c. Morphological and taxonomical comparison of the Cuban endemic taxa Ariadne, Mazaea, Acunaeanthus, Phyllomelia (Rubiaceae, Rondeletieae) and Eosanthe, with one new combination. Brittonia 51: 217-230.

Delprete, P.G. 1999d. Rondeletieae (Rubiaceae). Part I. Flora Neotropica Monogr 77: 1-226.

Delprete, P.G. 1999e. Melanopsidium Colla (Rubiaceae, Gardenieae): a little-known genus with a complex nomenclatural history. Brittonia 52: 325-336.

Delprete, P.G. 2001. Notes on some South America species of Psychotria subgenus Heteropsychotria (Rubiaceae), with observations on rubiaceous taxonomic characters. Brittonia 53: 396-404. 
Delprete, P.G. 2003a. Carapichea guianensis: the correct name for Psychotria carapichea (Rubiaceae), with a correction on the authority of $P$. carapichea, and a new combination in Carapichea. Brittonia 55: 88-89.

Delprete, P.G. 2003b. Revision and typification of some species of Ixora (Rubiaceae) from central and southern Brazil. Sida 20: 1471-1480.

Delprete, P.G. 2004a. Rubiaceae. In: Smith, N.P. et al. (eds.). Flowering plant families of the American tropics. Princeton University Press, New York Botanical Garden Press. Pp. 328-333.

Delprete, P.G. "2004b” [2005]. Chiococca plowmanii, a new species endemic to the coastal vegetation of northeastern Brazil, and a realignment of Chiococca nitida (Rubiaceae, Chiococceae). Revista de Biologia Neotropical 1: 4-10.

Delprete, P.G. 2006. Two new species of Coussarea and a new combination in Faramea (Rubiaceae, Coussareeae) from the Guianas. Blumea 50:355-364.

Delprete, P.G. 2007a. Ixora (Rubiaceae; S.L. JungMendaçolli, Coord.). In: Wanderley, M.G.L. et al. (eds.). Flora fanerogâmica do estado de São Paulo, Vol. 5. FAPESP, Hucitec, São Paulo. Pp. 354-357.

Delprete, P.G. 2007b. New combinations and new synonymies in the genus Spermacoce (Rubiaceae) for the Flora of Goiás and Tocantins (Brazil) and the Flora of the Guianas. Journal of the Botanical Research Institute of Texas 1: 1023-1030.

Delprete, P.G. 2008a. Three new species of Ixora (Rubiaceae) from the state of Tocantins, Brazil. Journal of the Botanical Research Institute of Texas 2: 455-462.

Delprete, P.G. 2008b. A revision of Tocoyena (Rubiaceae, Gardenieae) from the states of Goiás and Tocantins and a new species endemic to white sand areas in the Brazilian Cerrado. Journal of the Botanical Research Institute of Texas 2: 983-993.

Delprete, P.G. 2008c. A new species of Chomelia (Rubiaceae, Guettardeae) from the Brazilian Planalto. Blumea 53: 393-398.

Delprete, P.G. 2009a. Taxonomic history, morphology, and reproductive biology of the tribe Posoquerieae (Rubiaceae, Ixoroideae). Annals of the Missouri Botanical Garden 96: 79-89.

Delprete, P.G. 2009b. Rubiaceae. In: Feuillet, C. (ed.). Checklist of the plants of the Guiana Shield 1. An update to the Angiosperms. Journal of the Botanical Research Institute of Texas 3: 479-507.

Delprete, P.G. 2010a. Rubiaceae - Parte 1: Introdução, Gêneros A-H. In: Rizzo, J.A. (coord.). Flora dos estados de Goiás e Tocantins. Vol. 40. IRD/UFG, Universidade Federal de Goiás, Goiânia. Pp. 1-580.

Delprete, P.G. 2010b. Rubiaceae - Parte 2: Gêneros I-R. In: Rizzo, J.A. (coord.). Flora dos estados de Goiás e Tocantins. Vol. 40. IRD/UFG, Universidade Federal de Goiás, Goiânia. Pp. 581-1097.
Delprete, P.G. 2010c. Rubiaceae-Parte 3: Gêneros S-W, Índices. In: Rizzo, J.A. (coord.). Flora dos estados de Goiás e Tocantins. Vol. 40. IRD/UFG, Universidade Federal de Goiás, Goiânia. Pp. 1098-1610.

Delprete, P.G.; Achille, F. \& Mouly, A. 2010. Four new combinations in Chomelia and Stenostomum (Rubiaceae, Guettardeae) from Central America, the Guianas and the Amazon Basin. Blumea 55: 164-170.

Delprete P.G. \& Cortés-B., R. 2004. A phylogenetic study of the tribe Sipaneeae (Rubiaceae, Ixoroideae), using trnL-F and ITS sequence data. Taxon 53: 347-356.

Delprete, P.G. \& Cortés-B., R. "2006” [2007]. A synopsis of the Rubiaceae of the states of Mato Grosso and Mato Grosso do Sul, central-western Brazil, with a key to genera, and a preliminary species list. Revista de Biologia Neotropical 3: 13-96.

Delprete, P.G. \& Motley, T.J. 2003. Portlandia proctorii (Rubiaceae, Catesbaeeae), a new combination for a narrow endemic Jamaican species. Brittonia 55: 233-239.

Delprete, P.G. \& Nee, M. 1997. The enigmatic genus Wernhamia S. Moore is a synonym of Simira (Rubiaceae, Rondeletieae). Brittonia 49: 303-308.

Delprete, P.G.; Nee, M. \& Koek-Noorman, J. 2005. Resurrection and revision of Patima (RubiaceaeCinchonoideae-Hamelieae). Ann. Missouri Bot. Gard. 92: 103-112.

Delprete, P.G.; Smith, L.B. \& Klein, R.B. 2004. Rubiáceas. Vol. I - Gêneros de A-G: 1. Alseis até 19. Galium. (com observações ecológicas por Klein, R.; Reis, A. \& Iza, O.). In: Reis, A. (ed.). Flora ilustrada catarinense. Herbário Barbosa Rodrigues, Itajaí. Pp. 1-344.

Delprete, P.G.; Smith, L.B.\& Klein, R.B. 2005. Rubiáceas. Vol. 2 - Gêneros de G-Z: 20. Gardenia até 46. Tocoyena (com observações ecológicas por Klein, R.; Reis, A. \& Iza, O.). In: Reis, A. (ed.). Flora ilustrada catarinense. Herbário Barbosa Rodrigues, Itajaí. Pp. 345-843.

Delprete, P.G. \& Souza, E.B. 2004. Psychotria carrascoana (Rubiaceae, Psychortieae), a new species from the carrasco vegetation of northeastern Brazil. Novon 14: 158-162.

Delprete, P.G. \& Taylor, C.M. “2008” [2009]. Rubiaceae. In: Daly, D.C.; Silveira, M. \& Coll. (eds.). Primeiro catálogo da flora do Acre, Brasil/First catalogue of the flora of Acre, Brazil. EDUFAC, Rio Branco. Pp. 316-330.

Dempster, L.T. 1980. The genus Galium Section Lophogalium (Rubiaceae) in South America. Allertonia 2: 247-279.

Dempster, L.T. 1981. The genus Galium (Rubiaceae) in South America. II. Allertonia 2: 393-426.

Dempster, L.T. 1982. The genus Galium (Rubiaceae) in South America. III. Allertonia 3: 211-258. 
Dempster, L.T. 1990. The genus Galium (Rubiaceae) in South America. IV. Allertonia 5: 283-345.

Dempster, L.T. \& Delprete, P.G. 2004. Galium. In: Delprete, P.G.; Smith; L.B. \& Klein, R B. Rubiáceas. Vol. I-Gêneros de A-G: 1. Alseis até 19. Galium. In: Reis, A. (ed.). Flora ilustrada catarinense. Herbário Barbosa Rodrigues, Itajaí. Pp. 273-342.

Dessein, S. 2003. Systematic studies in the Spermacoceae (Rubiaceae). Doctoral Dissertation. K.U. Leuven, Leuven. 403p.

Dessein, S.; Andersson, L.; Geuten, K.; Smets, E. \& Robbrecht, E. 2005. Gomphocalyx and Phylohydrax (Rubiaceae) sister taxa excluded from Spermacoceae s.s., featuring remarkable case of convergent evolution. Taxon 54: 91-107.

Dessein, S.; Harwood, R.; Groeninckx, I. \& Robbrecht, E. 2006a. Diversity among Australian Spermacoce species. Third International Rubiaceae Conference - Programme \& Abstracts. Scripta Botanica Belgica 40: 30 .

Dessein, S.; Ntore, S.; Robbrecht, E. \& Smets, E. 2006b. Pollen and seeds reveal that Spermacoce thymoidea s.l. (African Rubiaceae, Spermacoceae) represents three endemic or disjunct species from the Zambezian high plateaus. Systematic Botany 28: 130-144.

Dessein, S.; Scheltens, A.; Huysmans, S.; Robbrecht, E. \& Smets, E. 2000. Pollen morphological survey of Pentas (Rubiaceae-Rubioideae) and its closest allies. Rev. Paleobot. Palynol. 112: 189-205.

De Vré, P. 2000. Pollenmorfologische studie van de Spermacoceae (Rubioideae - Rubiaceae). Undergraduate Thesis. Katholieke Universiteit Leuven, Leuven, Belgium. 135p.

Di Maio, F.R. “1996” [1997]. Revisão taxonômica do gênero Hindsia Bentham (Rubiaceae, Hedyotideae). Arquivos do Jardim Botânico do Rio de Janeiro 34: 51-92.

Di Maio, F.R. 2003. Estudo taxonômico das espécies de Ixora (Rubiaceae, Ixoreae) no Brasil extraamazônico. Doctoral Thesis. Universidade Federal do Rio de Janeiro, Rio de Janeiro. 145p.

Elias, T.S. 1976. A monograph of the genus Hamelia (Rubiaceae). Memoirs of the New York Botanical Garden 26: 81-144.

Erbar, C. 1991. Sympetaly - a systematic character. Botsche Jahrbücher für Systematik 112: 417-451.

Fay, M.F.; Bremer, B.; Prance, G.T.; Bank, M.; Bridson, D. \& Chase, M.W. 2000. Plastid rbcL sequence data show Dialypetalanthus to be a member of Rubiaceae. Kew Bulletin 55:853-864.

Forzza, R.C.; Leitman, P.M.; Costa, A.F.; Carvalho Jr., A.A.; Peixoto, A.L.; Walter, B.M.T.; Bicudo, C.; Zappi, D.; Costa, D.P.; Lleras, E.; Martinelli, G.; Lima, H.C.; Prado, J.; Stehmann, J.R.; Baumgratz,
J.F.A.; Pirani, J.R.; Sylvestre, L.; Maia, L.C.; Lohmann, L.G.; Queiroz, L.P.; Silveira, M.; Coelho, M.N.; Mamede, M.C.; Bastos, M.N.C.; Morim, M.P.; Barbosa, M.R.; Menezes, M.; Hopkins, M.; Secco, R.; Cavalcanti, T.B. \& Souza, V.C. 2010. Lista de espécies da flora do Brasil. Vols. I e II. Jardim Botânico do Rio de Janeiro, Rio de Janeiro. 1699p.

Funk, V.; Hollowell, T.; Berry, P.; Kelloff, C. \& Alexander, S.N. 2007. Checklist of the plants of the Guiana Shield (Venezuela: Amazonas, Bolívar, Delta Amacuro; Guyana, Surinam, French Guiana). Contributions from the United Staes National Herbarium 55: 1-584.

Germano Filho, P. “1998”[1999]. Estudos taxonômicos do gênero Bathysa C. Presl (Rubiaceae, Rondeletieae), no Brasil. Rodriguésia 50: 49-75.

Gomes, M. 2003a. Novas espécies de Coussarea Aubl. e Faramea Aubl. (Rubiaceae, tribo Coussareae). Acta Botanica Brasilica 17: 439-448.

Gomes, M. 2003b. Reavaliação taxonômica de algumas espécies dos gêneros Coussarea Aubl. e Faramea Aubl. (Rubiaceae, tribo Coussareae). Acta Botanica Brasilica 17: 449-466.

Govaerts, R. 1996. World checklist of seed plants. Vol. 2, part 1. Continental Publishing, Antwerp. 492p.

Govaerts, R.; Frodin, D.G.; Ruhsam, M.; Bridson, D.M. \& Davis, A.P. 2007. World checklist \& bibliography of Rubiaceae. The Trustees of the Royal Botanic Gardens, Kew.

Groenincks, I.; De Block, P.; Rakotonasolo, F.; Smets, E. \& Dessein, S. 2009a. Rediscovery of Malagasy Lathraeocarpa allows determination of its taxonomic position within Rubiaceae. Taxon 58: 209-226.

Groenincks, I.; Dessein, S.; Ochoterena, H.; Persson, C.; Motley, T.J.; Karehed, J.; Bremer, B. \& Smets, E. 2009 b. Phylogeny of the herbaceous tribe Spermacoceae (Rubiaceae) based on plastid DNA data. Annals of the Missouri Botanical Garden 96: 109-132.

Gustafsson, C.G.R. 1998. The Neotropical Rosenbergiodendron (Rubiaceae, Gardenieae). Brittonia 50: 452-466.

Gustafsson, C.G.R. \& Persson, C. 2002. Phylogenetic relationships among species of the neotropical genus Randia (Rubiaceae, Gardenieae) inferred from molecular and morphological data. Taxon 51: 661-674.

Hooker, J.D. 1873. Leptoscela ruellioides. Hooker's Icones Plantarum 12: 44-45, Pl. 1149.

Huysmans, S.; Robbrecht, E.; Delprete, P.G. \& Smets, E. 1999. Pollen morphological support for the Catesbaeeae-Chiococceae-Exostema-complex (Rubiaceae), a textbook case of the systematic value of pollen morphology. Grana 39: 325-338.

Jardim, J.G. \& Zappi, D. 2008a. Studies of Faramea Aubl. (Rubiaceae) in Brazil: two new species for 
Eastern Bahia $-F$. nocturna and $F$. biflora. Kew Bulletin 63: 131-136.

Jardim, J.G. \& Zappi, D. 2008b. Two new species of Faramea (Rubiaceae, Coussareae) from Eastern Brazil. Novon 18: 67-71.

Jardim, J.G. \& Zappi, D. 2008c. Carapichea lucida (Rubiaceae, Psychotrieae), a new species from Eastern Bahia, Brazil. Kew Bulletin 63: 661-664.

Jung-Mendaçolli, S.L. (coord.). 2007. Rubiaceae. In: Wanderley, M.G.L. (coord.). Flora fanerogâmica do estado de São Paulo. Vol. 5. Instituto de Botânica, São Paulo. Pp. 259-460.

Kainulainen, K.; Persson, C.; Eriksson, T. \& Bremer, B. 2010. Molecular systematics and morphological character evolution of the Condamineeae (Rubiaceae). American Journal of Botany 97: 1961-1981.

Karehed, J. \& Bremer, B. 2007. The systematics of Knoxieae (Rubiaceae) - molecular data and their taxonomic consequences. Taxon 56: 1051-1076.

Khan, S.A. 2007. New delimitations and phylogenetic relationships of Sabiceeae (Ixoroideae, Rubiaceae) and revision of the Neotropical species of Sabicea Aubl. Doctoral Dissertation. Bayreuth University. 351p.

Khan, S.A.; Razafimandimbison, S.G.; Bremer, B. \& Liede-Schumann, S. 2008. Sabiceeae and Virectarieae (Rubiaceae, Ixoroiodeae): one or two tribes? New tribal and generic circumscriptions of Sabiceeae and biogegraphy of Sabicea s.l. Taxon 57: 1-17.

Kirkbride, J.H. 1976. A revision of the genus Declieuxia (Rubiaceae). Memoirs of the New York Botanical Garden 28: 1-87.

Kirkbride, J.H. 1979. Raritebe, an overlooked genus of the Rubiaceae. Brittonia 31: 299-312.

Kirkbride, J.H. 1979. Revision of the genus Psyllocarpus (Rubiaceae). Smithsonian Contributions to Botany 41: 1-32.

Kirkbride, J.H. 1980. Manipulus rubiacearum - I. Acta Amazonica 10: 97-108.

Kirkbride, J.H. 1983. A new variety of Declieuxia cacuminis (Rubiaceae) from Bahia. Annals of the Missouri Botanical Garden 70: 204-205.

Kirkbride J.H. 1985. Manipulus rubiacearum IV. Kerianthera (Rubiaceae), a new genus from Amazonian Brazil. Brittonia 37: 109-116.

Kirkbride, J.H. 1997. Manipulus rubiacearum VI. Brittonia 49: 354-379.

Kuhlmann, J.G. 1925. Contribuição para o conhecimento de algumas plantas novas, contendo tambem um trabalho de critica e novas combinações. Archivos do Jardim Botânico de Rio Janeiro 4: 347-365.

Lantz, H., Andreasen, K. \& Bremer, B. 2002. Nuclear rDNA ITS sequence data used to construct the first phylogeny of Vanguerieae (Rubiaceae). Plant Systematics and Evolution 230: 173-187.
Lens, F.; Groenincks I.; Smets, E. \& Dessein, S. 2009. Woodiness within the Spermacoceae-Knoxieae alliance (Rubiaceae): retention of the basal woody condition in Rubiaceae or recent innovation? Annals of Botany 103: 1049-1064.

Lewis, W.H. \& Oliver, R.L. 1974. Revision of Richardia. Brittonia 26: 271-301.

Mabberley, D.J. 1997. The plant book: a portable dictionary of the vascular plants. Cambridge University Press, Cambridge. 858p.

Mabberley, D.J. 2008. Mabberley's plant book: a portable dictionary of plants, their classification and uses. Cambridge University Press, Cambridge. 1019p.

Macias, L.F.N. 1988. Revisão taxonômica do gênero Posoqueria Aubl. (Rubiaceae). Master Dissertation. Universidade Estadual de Campinas, Campinas. $171 \mathrm{p}$.

Macias, L.F.N. 1998. Estudos taxonômicos do gênero Manettia Mutis ex L. (Rubiaceae) no Brasil, Paraguai, Argentina e Uruguai. Tese de Doutorado. Universidade Estadual de Campinas, Campinas. 356p.

Margalho, L.F.; Rocha, A.E.S. \& Secco, R.S. 2009. Rubiaceae Juss. da restinga da APA de Algodoal/ Maiandeua, Maracanã, Pará, Brasil. Boletim do Museu Paraense Emílio Goeldi, Cienncias Naturais 4: 303-339.

Marques-Souza A.C.; Absy, M.L.; Miranda, I.P. de A. \& Küchmeister, H.E.C. 1993. Característica de flores, néctar y visitantes de Kerianthera preclara (Rubiaceae). Revista de Biologia Tropical 41: 483-489.

McDowell, T. 1996. Exostema (Rubiaceae): taxonomic history, nomenclature, position and subgeneric classification. Opera Botanica Belgica 7: 277-295.

McDowell, T. \& B. Bremer. 1998. Phylogeny, diversity, and distribution in Exostema (Rubiaceae): implications of morphological and molecular analyses. Plant Systematics and Evolution 212: 215-246.

Miatelo, J.H.B. 2008. Biodiversidade e distribuição da família Rubiaceae no Distrito Federal e nos estados de Goiás e Tocantins. Master Dissertation. Universidade Federal de Goiás, Goiânia. 70p.

Miatelo, J.H.B.; Delprete, P.G. \& De Marco Jr., P. 2010. Distribution and biodiversity of Rubiaceae in the Staes of Goiás and Tocantins and the Federal District, Central Brazil. In: Fifth International Rubiaceae and Gentianales Conference - Biodiversity in the light of Historical Information. The Royal Swedish Academy of Sciences and Stockholm University, Stockholm. P. 43.

Mori, S.A. 1992. Who will do the work? Brittonia 44: 372-375.

Motley, J.T.; Wurdack, K.J. \& Delprete, P.G. 2005. Molecular systematics of the CatesbaeeaeChiococceae complex (Rubiaceae): flower and 
fruit evolution and biogeographic implications. American Journal of Botany 92: 316-329.

Moura, M.V.L.P. 2001. Revisão taxonômica do gênero Alseis (Rubiaceae, Cinchonoideae). Tese de Doutorado. Universidade de São Paulo, São Paulo. 141p.

Nepokroeff, M.; Bremer, B. \& Systma, K.J. 1999. Reorganization of the genus Psychotria and tribe Psychotrieae (Rubiaceae) inferred from ITS and rbcL sequence data. Systematic Botany 24: 5-27.

Nicholas, A. \& Baijnath, H. 1994. A consensus classification for the order Gentianales with additional details on the suborder Apocyninae. Botanical Review 60: 440-482.

Oliveira, C.T.; Giacomin, L. \& Zappi, D.C. 2011. Kerianthera longiflora (Rubiaceae), a remarkable new species from eastern Brazil, with some observations on K. preclara. Kew Bulletin 66: 1-6.

Pantoja, S.C.S. 1994. Revisão taxinômica do gênero Warscewiczia Klotzsch (Rubiaceae, Rondeletieae). Master Dissertation. Universidade Federal de Rio de Janeiro, Rio de Janeiro. 110p.

Parks, A. \& McDowell, T. (accepted). In: Delprete, P.G. (coord.). Rubiaceae, Part I: Introduction, key to genera, and genera from A to L. In: Jansen-Jacobs, M.J. (ed.). Flora of the Guianas. Kew Botanic Gardens.

Pereira, M.S. \& Barbosa, M.R. 2004. A família Rubiaceae na Reserva Biológica Guaribas, Paraiba, Brasil. Subfamílias Antirheoideae, Cinchonoideae e Ixoroideae. Acta Botanica Brasilica 18: 305-318.

Pereira, M.S. \& Barbosa, M.R. 2006. A família Rubiaceae na Reserva Biológica Guaribas, Paraiba, Brasil. Subfamília Rubioideae. Acta Botanica Brasilica 20: 455-470.

Persson, C. 2000a. Phylogeny of the Neotropical Alibertia group (Rubiaceae), with emphasis on the genus Alibertia, inferred from ITS and 5S ribosomal DNA sequences. American Journal of Botany 87: 1018-1028.

Persson, C. 2000b. Phylogeny of Gardenieae (Rubiaceae) based on chloroplast DNA sequences from $r p s 16$ intron and $\operatorname{trn} \mathrm{L}(\mathrm{UAA})-\mathrm{F}(\mathrm{GAA})$ intergenic spacer. Nordic Journal of Botany 20: 257-269.

Persson, C. 2003. Agouticarpa, a new neotropical genus of the tribe Gardenieae (Rubiaceae). Brittonia 55: 176-201.

Persson, C. 2005. New combinations in Kutchubaea (Gardenieae-Rubiaceae). Revista de Biologia Neotropical 2: 65-74.

Piesschaert, F.; Robbrecht, E. \& Smets, E. 1997. Dialypetalanthus fuscescens Kuhlm. (Dyalipetalanthaceae): the taxonomic position of an Amazonian endemic. Annals of the Missouri Botanical Garden 84: 201-223.

Pire, S.M. 1997. Género Galianthe subg. Ebelia (Rubiaceae: Spermacoceae): estudio palinológico. Annals of the Missouri Botanical Garden 84: 878-887.
Pire, S.M. \& Cabral, E.L. 1992. El valor del polen en la revaliación de Galianthe (Spermacoceae-Rubiaceae). Darwiniana 31: 1-10.

Prado, A.L. 1987. Revisão taxonômica do gênero Tocoyena Aubl. (Rubiaceae) no Brasil. Dissertação de Mestrado. Universidade Estadual de Campinas, Campinas. 194p.

Puff, C. (ed.). 1991a. The genus Paederia L.: a multidisciplinary study. Opera Botanica Belgica 3: $1-376$.

Puff, C. 1991b. Revision of the genus Paederia L. (Rubiaceae-Paederieae) in America. Opera Botanica Belgica 3: 325-333.

Razafimandimbison, S.G.; McDowell, T.D.; Halford, D.A. \& Bremer, B. 2009. Molecular phylogenetics and generic assessment in the tribe Morindae (Rubiaceae-Rubioideae): how to circumscribe Morinda L. to be monophyletic? Molecular Phylgenetics Evolution 52: 879-886.

Rizzini, C. T. \& Occhioni, P. 1949. Dyalipetalanthaceae. Lilloa 17: 243-288.

Robbrecht, E. 1988. Tropical woody Rubiaceae. Characteristic features and progressions. Contributions to a new subfamilial classification. Opera Bot. Belg. 1: 1-271.

Robbrecht, E. "1993” [1994]. (Editor). Advances in Rubiaceae macrosystematics. Opera Botanica Belgica 6: 1-200.

Robbrecht, E. \& Manen, J.F. 2006. The major evolutionary lineages of the coffee family (Rubiaceae, angiosperms). Combined analysis (nDNA and cpDNA) to infer the position of Coptosapelta and Luculia, and supertree construction based on rbcL, rps16, trnL-trnF anf atpB-rbcL data. A new classification in two subfamilies, Cinchonoideae and Rubioideae. Systematics and Geography of Plants 76: 85-145.

Rogers, G.K. 1984. Gleasonia, Henriquezia, and Platicarpum (Rubiaceae). Flora Neotropica Monograph 39: 1-135.

Rova, J.H.E. 1999. The Condamineeae-RondeletieaeSipaneeae complex (Rubiaceae). Doctoral Dissertation. Göteborg University, Göteborg. 29p.

Rova, J.H.E.; Delprete, P.G. \& Bremer, B. 2009. The Rondeletia complex (Rubiaceae): An attempt to use ITS, $r p s 16$, and $t r n \mathrm{~L}-\mathrm{F}$ sequence data to delimit Guettardeae, Rondeletieae, and sections within Rondeletia. Annals of the Missouri Botanical Garden 96: 182-193.

Rova, J.H.E.; Delprete, P.G.; Andersson, L. \& Albert, V.A. 2002. A trnL-F cpDNA sequence study of the Condamineeae-Rondeletieae-Sipaneeae complex with implications on the phylogeny of the Rubiaceae. American Journal of Botany 89: 145-159.

Rydin, C.; Razafimandimbison, S.G.; Bremer, B. 2008. Rare and enigmatic genera (Dunnia, Schizocolea, 
Colletoecema), sisters to species-rich clades: Phylogeny and aspects of conservation biology in the coffee family. Molecular Phylogenetics and Evolution 48: 74-83.

Salas, R.M. 2007. Staelia. In: Wanderley, M.G.L. et al. (coord.). Flora fanerogâmica do estado de São Paulo. Vol. 5. Instituto de Botânica, São Paulo. P. 442.

Salas, R.M. \& Cabral, E.L. 2010a. Planaltina nuevo género de la tribu Spermacoceae (Rubiaceae), emdémico del Planalto Central de Brasil y una nueva especie del estado de Goiás, Brasil. Journal of the Botanical Research Institute of Texas 4: 193-206.

Salas, R.M. \& Cabral, E.L. 2010b. The species of the genus Staelia (Rubiaceae) from Paraguya, a new species and new synonyms. Blumea 123-128.

Sano, S.M.; Almeida, S.P. \& Ribeiro, J.F. (Editores). 2008. Cerrado: ecologia e flora. 2 vols. Embrapa Cerrados, Brasília. 1279p.

Schumann, K. 1889. Rubiaceae, tribus X-XIX. In: Martius, C.F.P. et al. (eds.). Flora brasiliensis. Fleischer, Leipzig. Vol. 6(6), pp. 125-466.

Schumann, K. 1891. Rubiaceae. In: Engler, A. \& Prantl, K. (eds.). Die Natürlichen Pflanzenfamilien. Engelmann, Leipzig. Vol. 4(4), pp. 1-156.

Silberbauer-Gottsberger, I., Gottsberger, G. \& Erhendorfer, F. 1992. Hybrid speciation and radiation in the neotropical woody genus Tocoyena. Plant Systematics and Evolution 181: 143-169.

Small, J.K. 1913. Flora of Miami. New York, published by the author. $206 \mathrm{p}$.

Sprague, T.A. 1928. Diacrodon. Bulletin of Miscellaneous Information Kew 1928: 33.

Souza, E.B. 2008. Estudos Sistemáticos em Mitracarpus Zucc. ex Shult. \& Schult. f. (Rubiaceae-Spermacoceae) com ênfase em espécies brasileiras.Universidade Estadual de Feira de Santana, Bahia. 188p.

Souza, E.B.; Cabral, E.L. \& Zappi, D.C. 2010. Revisão de Mitracarpus (Rubiaceae-Spermacoce) para o Brasil. Rodriguésia 61: 319-352.

Steyermark, J.A. 1964. Rubiaceae. In: Maguire, B.; Wurdak, J.J. \& colls. Botany of the Guayana Highlands, Part V. Memoirs of the New York Botanical Garden 10: 186-278.

Steyermark, J.A. 1965. Rubiaceae. In: Maguire, B.; Wurdak, J.J \& colls. Botany of the Guayana Highlands. Part VI. Memoirs of the New York Botanical Garden 12: 178-285.

Steyermark, J.A. 1967. Rubiaceae. In: Maguire, B.; Wurdak, J.J \& colls. Botany of the Guayana Highlands. Part VII. Memoirs of the New York Botanical Garden 17: 230-436.

Steyermark, J.A. 1972. Rubiaceae. In: Maguire, B.; Wurdak, J.J \& colls. Botany of the Guayana Highlands. Part IX. Memoirs of the New York Botanical Garden 23: 227-832.
Steyermark, J.A. 1974. Rubiaceae. In: Lasser, T. \& Steyermark, J.A. (eds.). Flora de Venezuela. Vol. 9, pars 1-3. Instituto Botánico, Caracas. Pp. 1-2070.

Steyermark, J.A. 1987. Perama dichotoma. Annals of the Missouri Botanical Garden 74: 658.

Steyermark, J.A. \& Kirkbride, J.H. 1977. Review of the genus Perama (Rubiaceae). Brittonia 29: 191-198.

Stoffelen, P.; Robbrecht, E. \& Smets, F.L.S. 1996. A revision of Corynanthe and Pausinystalia (African Rubiaceae-Coptosapelteae). Botanical Journal of the Linnaean Society 120: 287-326.

Struwe, L. \& Albert, V. (eds.). 2002. Gentianaceae, systematics and natural history. Cambridge University Press, New York. 652p.

Struwe, L.; Albert, V.A. \& Bremer, B. "1994” [1995]. Cladistics and family-level classification of the Gentianales. Cladistics 10:175-206.

Takhtajan, A.L. 1997. Diversity and classification of flowering plants. Columbia University Press, New York. 643p.

Taylor, C.M. 1992. Revision of Cosmibuena (Rubiaceae). Annals of the Missouri Botanical Garden 79: 886-900.

Taylor, C.M. 1994. Revision of Hillia (Rubiaceae). Annals of the Missouri Botanical Garden 81: 571-609.

Taylor, C.M. 1996. Overview of the Psychotrieae (Rubiaceae) in the Neotropics. Opera Bot. Belg. 7: 261-270.

Taylor, C.M. 1997. Conspectus of the genus Palicourea (Rubiaceae: Psychotrieae) with the description of some new species from Ecuador and Colombia. Annals of the Missouri Botanical Garden 84: 224-262.

Taylor, C.M. 2001a. Rubiaceae. In: Stevens, W.D. et al. (eds.). Flora of Nicaragua. Monographs in Systematic Bototany 85. Missouri Botanical Garden, St. Louis.

Taylor, C.M. 2001b. Overview of the Neotropical genus Notopleura (Rubiaceae, Psychotrieae), with the description of some new species. Annals of the Missouri Botanical Garden 88: 478-515.

Taylor, C.M. 2004. The neotropical genus Ronabea (Rubiaceae, Lasiantheae). Systematics and Geography of Plants 74: 35-42.

Taylor, C.M. 2005. Margaritosis (Rubiaceae, Psychotrieae) in the Neotropics. Systematics and Geography of Plants 75: 161-177.

Taylor, C.M. 2006. Carapichea. Tribe 18. Psychotrieae (2). In: Harling, G. \& Persson, C. (eds.). Flora of Ecuador. Vol. 79. Department of Plant and Environmental Sciences, Gothenburg University, Gothenburg. Pp. 5-8.

Taylor, C.M.; Campos, M.T.V. \& Zappi, D. 2007. Flora da Reserva Ducke, Amazonas, Brasil: Rubiaceae. Rodriguésia 58: 549-616.

Taylor, C.M. \& Cortés-B., R. 1999. Una nueva especie de Posoqueria (Rubiaceae) de la Guayana Colombiana. Novon 9: 428-430. 
Taylor, C.M. \& Gereau, R.E. 2010a. Rubiacearum americanarum magna hama pars XXIII: Overview of the Guettardeae tribe in Central and South America, with five new species and three new combinations in Chomelia, Neoblakea, Pittoniotis, and Stenostomum. Novon 20: 351-362.

Taylor, C.M. \& Gereau, R.E. 2010b. Rubiacearum americanarum magna hama pars XXIV: New species of Central and South American Bouvardia, Hillia, Joosia, Ladenbergia, Pentagonia, and Posoqueria. Novon 20: 470-480.

Taylor, C.M.; Lorence, D.H. \& Gereau, R.E. 2010. Rubiacearum americanarum magna hama pars XXV: The nocturnally flowering species of Psychotria domingensis-Coussarea hondensis group plus three other Mesoamerican Psychotria species transfer to Palicourea. Novon 20: 481-492.

Taylor, C.M. \& Lorence, D.H. 2010. Rubiacearum americanarum magna hama pars XXII: Notable new species of South American Coutarea, Morinda, Patima, and Rosenbergiodendron. Novon 20: 95-105.

Taylor, C.M.; Steyermark, J.A.; Delprete, P.G.; Vicentini, A.; Cortés, R.; Zappi, D.; Persson, C.; Costa C.B. \& Anunciação, E.A. 2004. Rubiaceae. In: Steyermark, J.A. et al. (eds.). Flora of the Venezuelan Guyana Vol. 8. Missouri Botanical Garden Press, St. Louis. Pp. 497-874.

Taylor, D.W. 2003. A taxonomic revision of the genus Chione (Rubiaceae). Systematics and Geography of Plants 73: 171-198.

Terrell E.E. \& Wunderlin, R.P. 2002. Seed and fruit characters in selected Spermacoceae and comparison with Hedyotideae (Rubiaceae). Sida 20: 549-557.

Thiers, B. [continuously updated]. Index Herbariorum: A global directory of public herbaria and associated staff. New York Botanical Garden's Virtual Herbarium. Available in $<$ http://sweetgum.nybg. org/ih/>. Access on 7 Jan 2012.

Vaes, E.; Vrijdaghs, A.; Smets, E. \& Dessein, S. 2006. Elaborate petals in Australian Spermacoce (Rubiaceae) species: morphology, ontogeny and function. Annals of Botany 98: 1167-1178.

Verdcourt, B. 1958. Remarks on the classification of the Rubiaceae. Bulletin du Jardin Botanique de l'État 28: 209-281.

Vicentini, A. 2007. Pagamea Aubl. (Rubiaceae), from species to processes, building the bridge. Ph.D. Thesis. University of Missouri, Saint Louis. 318p.

Wunderlich, R. 1971. Die systematische Stellung von Theligonum. Oesterreichische Botanische Zeitung 119: 329-394.

Zappi, D.C. 2003. Revision of Rudgea (Rubiaceae) in southeastern and southern Brazil. Kew Bulletin 58: 513-596.

Zappi, D.C. \& Nunes, T.S. 2000. Notes on The Rubiaceae of Northeastern Brazil I. Erithalis, Psychotria and Rudgea. Kew Bulletin 55: 655-668.

Zappi, D.C. \& Nunes, T.S. 2002. Preliminar checklist of Rubiaceae in Northeastern Brazil. Royal Botanic Gardens, Kew. 50p.

Zappi, D.C. \& Stannard, B.L. 1995. Rubiaceae. In: Stannard, B.L. (ed.). Flora of the Pico das Almas, Chapada Diamantina - Bahia, Brazil. The Trustees of the Royal Botanic Garden, Kew. Pp. 546-578.

Zappi, D.C.; Cabral, E.L.; Smith, S.F.; Souza E.B. \& Delprete, P.G. 1998. Rubiaceae. In: Ferreira de Sales, M.; Mayo, S.J. \& Rodal, M.J.N. (eds.). Plantas vasculares das florestas serranas de Pernambuco. Universidade Federal de Pernambuco, Impresa Universitaria. Pp. 94-98. 